\title{
Time to Say 'Good Buy' to the Passive Consumer? A Conceptual Review of the Consumer in the Bioeconomy
}

\author{
Ulrich Wilke $^{1}$ (D) Michael P. Schlaile ${ }^{2,3}$ (D) Sophie Urmetzer ${ }^{2,4}$ (D) \\ Matthias Mueller ${ }^{2}$ (D) Kristina Bogner ${ }^{5}$ (D) . Andreas Pyka ${ }^{2}$ (D)
}

Accepted: 10 June 2021 / Published online: 28 June 2021

(c) The Author(s) 2021

\begin{abstract}
Successful transitions to a sustainable bioeconomy require novel technologies, processes, and practices as well as a general agreement about the overarching normative direction of innovation. Both requirements necessarily involve collective action by those individuals who purchase, use, and co-produce novelties: the consumers. Based on theoretical considerations borrowed from evolutionary innovation economics and consumer social responsibility, we explore to what extent consumers' scope of action is addressed in the scientific bioeconomy literature. We do so by systematically reviewing bioeconomy-related publications according to (i) the extent to which consumers are regarded as passive vs. active, and (ii) different domains of consumer responsibility (depending on their power to influence economic processes). We find all aspects of active consumption considered to varying degrees but observe little interconnection between domains. In sum, our paper contributes to the bioeconomy literature by developing a novel coding scheme that allows us to pinpoint different aspects of consumer activity, which have been considered in a rather isolated and undifferentiated manner. Combined with our theoretical considerations, the results of our review reveal a central research gap which should be taken up in future empirical and conceptual bioeconomy research. The system-spanning nature of a sustainable bioeconomy demands an equally holistic exploration of the consumers' prospective and shared responsibility for contributing to its coming of age, ranging from the procurement of information on bio-based products and services to their disposal.
\end{abstract}

Keywords Consumer $\cdot$ Innovation $\cdot$ Consumer responsibility $\cdot$ Shared responsibility $\cdot$ Sustainable bioeconomy $\cdot$ Transition

Michael P. Schlaile

schlaile@uni-hohenheim.de

Extended author information available on the last page of the article 


\section{Introduction}

The bio-based economy or, in short, bioeconomy has been promoted by both researchers and policymakers as a viable response to various societal challenges such as health issues and food security. The bioeconomy is also associated with multiple positive impacts on sustainability such as green growth, job creation, rural regeneration, and climate change mitigation (Bugge et al., 2016; McCormick \& Kautto, 2013; Meyer, 2017; Pyka, 2017). ${ }^{1}$ Around 50 nation states and the European Union (EU) have adopted bioeconomy strategies or related policies (Bioökonomierat, 2018), and the number of academic papers on this topic is growing rapidly with contributions stemming from researchers around the globe and from different scientific disciplines. ${ }^{2}$ Notably, there is still a great diversity in the notions of bioeconomy (Hausknost et al., 2017), which can be clustered into different ideal types ranging from the idea of increasing the use of biotechnology for industrial purposes to grounding all economic activities on the use of renewable biogenic resources (e.g., Bracco et al., 2018; Bugge et al., 2016; Hausknost et al., 2017; Meyer, 2017; Vivien et al., 2019). In addition to this conceptual diversity, one cannot expect that a bioeconomy will necessarily have a positive impact on sustainability. Quite to the contrary, unsustainable bioeconomies are easily conceivable, for example, resulting from the spread of high-risk technologies, excessive land and water use, deforestation, biodiversity loss, reduced food security, and unjust allocation of profits and burdens, to name just a few (Grefe, 2018; Lewandowski, 2015; O'Brien et al., 2017; Pfau et al., 2014; Smolker, 2008; Székács, 2017). ${ }^{3}$ Consequently, to legitimize the political enforcement of a sustainable bioeconomy, it must always be measured against its contribution to meeting the grand societal challenges of our time (Vogt, 2018). If implemented accordingly, the sustainable bioeconomy can serve as an "innovation program" for sustainable development (Vogt, 2020). To achieve this, the bioeconomy transition must be regarded as a deeply normative endeavor that requires ethical

\footnotetext{
1 We understand sustainability as a deeply normative concept/orientation with (at least) three dimensions (economic, social, and environmental), also comprising an intergenerational component. As with most normative concepts, there is an ongoing debate about the notion of sustainability, its scope, meaning, limitations, and implications, especially as there is ample potential for tension between the three dimensions of sustainability; and it may not be so clear what part of a system should be sustained or transformed, why, and by / for whom (see also Schlaile et al., 2017; Schlaile \& Urmetzer 2021). Notably, the controversy around sustainability is not limited to academia. For example, Olde and Valentinov (2019) illustrate the ongoing debates about sustainability in Western agricultural systems, for which they do not see any consensus arising between the involved groups in the nearby future, due to the underlying moral complexity.

2 The results of a search on Scopus with the query ("bio economy" OR "bioeconomy" OR "bio-based economy") in the field TITLE-ABSTRACT-KEYWORD showed one document in the year 2000, 43 documents in 2010 and 461 documents in 2019. The authors of these documents had affiliations to organizations from 94 different countries, with the five most frequent countries of origin being Germany ( $16.1 \%$ of results), the United States $(13.5 \%)$, the United Kingdom $(9.1 \%)$, Italy $(8.3 \%)$, and the Netherlands $(6.7 \%)$.

3 Not to mention the general tension between using biomass for food versus using it as material and energy for industrial processes (OECD, 2018)
} 
guardrails and public discourse (Kröber \& Potthast, 2015; Vogt, 2020) instead of purely supply-oriented reverie. In contrast to inquiries into aspects regarding what is technologically possible, Sanz-Hernández et al. (2019) identify a gap in research into the social scientific aspects of a bioeconomy and others have argued that there is insufficient scholarly debate on what is normatively desirable for a bioeconomy (Urmetzer et al., 2018, 2020) - a trend which is also reflected in a public bioeconomy funding bias towards high-tech developments (Bogner, 2019; Ober \& Huwe, 2020). When it comes to the question whether it is the supply of new technologies or the needs and desires of societies that drives socio-economic changes, we know (not only) from the literature on innovation economics that the story is much more complex than the simplifying dichotomy of "technology push" vs. "demand pull" may suggest (e.g., see Godin \& Lane, 2013 for a detailed review). Yet, at a first glance, the contemporary bioeconomy literature appears to be somewhat biased in the sense of an implicit technology push focus.

Indeed, this perceived imbalance prompted us to scan the recent research landscape on bioeconomy more systematically. More concretely, we aim to explore the extent to which consumers are recognized as active agents in a bioeconomy context. It should be noted, however, that consumers (or, from an aggregated perspective, the "demand side") have been the subject of controversial debates especially regarding their contribution to social, ecological, and economic sustainability: For example, consumers have been argued to play an important role in various processes of economic change and novelty creation (e.g., Grabher \& Ibert, 2018; Hoffmann, 2007; Müller, 2017; Schlaile et al., 2018b; von Hippel, 2005; von Hippel et al., 2011), and, more specifically, even in system-wide innovations such as sustainability transitions (e.g., Köhler et al., 2019, Sect. 7; Randelli \& Rocchi, 2017), including transitions to a sustainable bioeconomy (Daniel \& Reisch, 2014; Rösch \& Scheer, 2020). On the other hand, there are good points against overestimating the transformative potential of ethical consumption and political consumerism (e.g., Devinney et al., 2010; Gjerris et al., 2016; Grunwald, 2012; Jacobsen \& Dulsrud, 2007). Consequently, with our literature review we do not contend that consumers play a more important role in the bioeconomy transition than other economic agents; nor do we expect our review to be able to support any claim in favor or against this contention. Based on prominent debates in innovation economics and inspired by the recent literature on consumer responsibility, however, we deem it essential to explore the way consumers are considered in the recent bioeconomy literature. More concretely, our analysis addresses the following research question: To what extent does the scientific bioeconomy literature capture the different roles and activities of consumers?

The paper is organized as follows. The following section covers the theoretical background in detail, motivating this paper's focus on consumers in the bioeconomy-especially against the background of innovation economics and the literature on (prospective) shared responsibility. Subsequently, we present the systematic literature review by describing the method applied and by depicting the results. The fourth section discusses the results before we conclude our paper with a summary and avenues for future research. 


\section{Theoretical Background}

\section{Why the Bioeconomy is More than a Supply-side Endeavor}

Scientists, politicians, and industrial actors around the world have acknowledged the potential contribution of a bioeconomy to climate protection while also recognizing its potential as a driver for employment, innovation, and increased resource productivity (Carus et al., 2011; European Commission, 2018a; Pyka, 2017; Staffas et al., 2013). However, visions of what exactly a bioeconomy entails - and expectations of its positive effects - vary widely (e.g., Bugge et al., 2016; D’Amato et al. 2017; Hausknost et al., 2017; Levidow et al., 2013; Möller et al., 2020; Oekom e.V., 2020; Pfau et al., 2014; Vivien et al., 2019; Zwier et al., 2015).

The perception of the bioeconomy propagated, for instance, by the OECD and the US-American administration (OECD, 2018; The White House, 2012) displays a strong focus on technological innovation. It thus neglects resolution strategies for potential trade-offs, conflicting goals, and unintended consequences. Moreover, it ignores normative considerations such as visions of the type of society the bioeconomy intends to support (Hausknost et al., 2017; Ober \& Huwe, 2020). For the European Commission, however, strengthening the bioeconomy has a clearly defined normative goal: the bioeconomy is seen as an important steppingstone to achieving many of the United Nations' Sustainable Development Goals (SDG). ${ }^{4}$ Therefore, a central feature of the European understanding is a commitment to a bioeconomy that safeguards sustainability, modernization, and environmental protection (European Commission, 2018a).

This more holistic perception of the concept entails an understanding of the bioeconomy as a change process. The transition perspective from a fossil-based economy towards an economy that is fit for the future is also echoed in the strategy of the German Federal Government (BMBF and BMEL, 2020). Its focus on "a structural transition from an economy based on finite resources of fossil origin... to an economy more strongly based on renewable resources" (BMEL, 2014, p. 14, emphasis added) abandons the fixation on certain sectors and particular technologies. Instead, the search for solutions to unprecedented challenges requires the creation of new holistic knowledge for better understanding those global biological systems that provide the basis for sustainable economic development (BMBF and BMEL, 2020; de Vries et al., 2021; Urmetzer et al., 2018, 2020).

Against this backdrop and in the context of our paper, we premise that bioeconomy solutions must not be regarded as ends in themselves that are expected to automatically increase sustainability in one way or another (see also Székács,

\footnotetext{
${ }^{4}$ In this context, the SDGs as internationally agreed normative goals should be seen as a compromise covering a wide range of different themes. They also reflect multiple tensions between the three pillars of sustainable development, namely, the economic, the social, and the environmental one. Consequently, different aspects of the SDGs have been criticized, ranging from an underrepresentation of environmental issues to the broad range of SDGs and difficulties of measuring the underlying targets and indicators (e.g., Hák et al., 2016). A related critique revolves more generally around neglecting the normative complexity and process dimensions of transformations (e.g., Schlaile \& Urmetzer 2021; Schlaile et al., 2017).
} 
2017). Instead, we follow Vogt (2020) in interpreting the sustainable bioeconomy as an endeavor that operationalizes the innovative aspect(s) of sustainability (Vogt, 2020 , p. 30). In other words, the bioeconomy can be an important driver of the required transformation that aligns the multiple innovative efforts of various actors in many areas to the ethical goals of a sustainable society (Vogt, 2018, 2020, see also Urmetzer, 2020). Yet, if we consider the bioeconomy to rely on (sustainable and responsible) innovations, we should be careful not to over-emphasize the role of the "supply side" and technologies as the main driver of economic change as promoted by the dominant "techno-economic paradigm" (Blok, 2020). To be clear, new technological solutions developed by firms and other "producers" are undoubtedly important. However, focusing solely on the production of new technologies may run the danger of neglecting, for example, the path dependence and resistance to change of technological regimes and socio-technical systems (e.g., Dosi, 1982; Geels, 2002) as well as the necessary non-technological (e.g., social and transformative) innovations and an adequate societal implementation (see also Blok, 2020; Loorbach et al., 2020). Indeed, without due consideration of the demand side impact of novelties beyond market uptake, technological advancements may even be voided or actually corrupted by unsustainable consumption habits (see also Daniel \& Reisch, 2014, on a related note) - a ramification that has been dubbed rebound effect (e.g., Greening et al., 2000; Herring \& Roy, 2007). ${ }^{5}$ And finally, as also Randelli and Rocchi (2017, p. 95) highlight, there is an increasing number of studies that actually support "an active role of consumers in the innovation process and recognise that consumers cannot be conceived only as passive agents who select between different commercial options."

In the following two subsections, we outline some of the fundamental theoretical cornerstones that motivated our literature review, which aims to illuminate how the consumers' capacity for taking an active role is represented in the scientific bioeconomy literature. Here, we draw from two different (but interrelated) schools of thought: The contemporary literature in (evolutionary) innovation economics (e.g., Pyka, 2017, 2019, 2020) teaches us about the important function(s) and influence of various actors in innovation systems and innovation networks, including consumers (Schlaile et al., 2018b), while the recent literature on consumer social responsibility (e.g., Heidbrink \& Müller, 2020; Schlaile et al., 2018a; Schmidt, 2016) helps to fathom the role(s) of consumers in co-defining the normative directionality of (bio-) economic systems against the backdrop of a prospective and shared responsibility.

\footnotetext{
5 This effect has, for instance, been observed with recycled materials that are produced to substitute primary resources. In many cases and for various reasons, such recycled materials (e.g., aluminum, paper, or plastics) are not demanded to the expected extent, which is why they are likely to be produced in addition to-rather than instead of - primary ones, thus reducing the potential benefits of recycling (Zink and Geyer 2017).
} 


\section{The Consumer in Innovation Economics}

From an innovation economics perspective, the role of the consumer in innovation processes has long been under great debate (for a more exhaustive recapitulation, see Godin \& Lane, 2013). The origins of this debate can be traced back at least to the seminal work of Schmookler, who argued already in the 1960s for the importance of market demand by showing through a set of studies that patterns in patenting activities followed consumption patterns in certain industries (Schmookler, 1962). From these studies, he concluded that demand is key to explaining changes in an economy (cf. Müller, 2017, for a more detailed presentation of this argument).

Since then, several studies have attempted to support Schmookler's hypothesis that innovation follows demand while others viewed the activities and internal capabilities of firms as the primary drivers of innovation (e.g., Teece, 1986) and argued against Schmookler's interpretation. Notably, proponents against this "demand pull" perspective on innovation followed the ideas and arguments by Schumpeter (1943), who focused in his work more on the role of monopolists and entrepreneurs (see also Nelson \& Consoli, 2010, on a related note). In fact, the paradigm of a passive consumer is lucidly summarized with the following quote by Schumpeter, which has also been highlighted by Korthals (2001):

"It is ... the producer who as a rule initiates economic change, and consumers are educated by him if necessary; they are, as it were, taught to want new things, or things which differ in some respect or other from those which they have been in the habit of using" (Schumpeter, 1983, p. 65).

As a preliminary result of the debate between this demand-side vs. supply-side centered view on innovation, it was Mowery and Rosenberg (1979) who linked both contrasting views and argued that both sides appear to simultaneously play crucial roles:

"Rather than viewing either the existence of a market demand or the existence of a technological opportunity as each representing a sufficient condition for innovation to occur, one should consider them each as necessary, but not sufficient, for innovation to result; both must exist simultaneously" (Mowery \& Rosenberg, 1979, p. 143).

This seemingly appeasing verdict did not lead to a balanced consideration of both the demand side and the supply side in the literature (Godin \& Lane, 2013). In fact, many authors have argued that despite the intense debate in the 1960s and 1970s the demand side and the consumer are still underrepresented in the innovation economics literature (e.g., Coombs, 2001; Müller, 2017; Nelson \& Consoli, 2010; Schlaile et al., 2018b). However, at the same time, we also see that the debate has, in the meantime, branched out into a number of sub-debates and research fields, each of which highlighting different aspects of the consumers' role(s) in innovation processes. With this, we see a more comprehensive analysis of the multifaceted relation between demand and innovation as, for example, 
Andersen (2007) points out. Possible examples cover the study of the diffusion of innovations (Rogers, 2003), including the more recent re-framing of diffusion in terms of a co-creative process (Vargo et al., 2020), and furthermore, the approaches of "democratizing" and "free" innovation (von Hippel, 2005, 2017), or the literature on evolutionary economics and economic geography arguing for a more prominent role of users and consumers in co-creating novelties (e.g., Chai \& Baum, 2019; Grabher \& Ibert, 2018; Grabher et al., 2008). In the context of the bioeconomy, examples of the centrality of users' knowledge for innovation have specifically been discovered for food technologies (Cappellesso \& Thomé, 2019) or for the development of a forest-based bioeconomy (Grundel \& Dahlström, 2016). The literature on innovation systems has long acknowledged the importance of user-producer interactions (e.g., Lundvall, 2016). Authors recently re-emphasized the importance of innovation system actors beyond the traditional "producers" of scientific and technological knowledge (e.g., Schlaile et al., 2017; Urmetzer \& Pyka, 2021). That explicitly includes consumers (e.g., Randelli \& Rocchi, 2017; Schlaile et al., 2018b).

By taking the centrality of innovation for a sustainable bioeconomy transition seriously (e.g., Pyka, 2017; Vogt, 2020), this discussion implies that active consumers may also be important in and for this structural transition. Do we then simply need to enforce an increased consumption of bio-based products? This might be the alleged aim of the European Commission when calling - in their bioeconomy strategy-for policy instruments that help "to boost market uptake and consumer confidence" (European Commission, 2018a, p. 11) in order to promote bio-based innovations and products. Such policy instruments originate from the dominant bioeconomy narratives that have traditionally focused on research and innovation policies (Birch et al., 2010) and framed sustainability problems as efficiency problems that can be overcome by biotechnological progress and green growth (Hausknost et al., 2017; Székács, 2017; Vivien et al., 2019). However, the requirement of sustainability awards yet another role to the consumer: the negotiator of the ethical standards and the social desirability of this structural transition. The consumer helps define "the aims, contours, limits, moral standards and principles of that future economic model" (Hausknost et al., 2017, p. 19). In the same vein, the literature on responsible innovation argues that the directionality and desirability of novelties (technological and non-technological alike) cannot be determined by the "producers" alone and needs active engagement from stakeholders to innovate for and with society (e.g., Gianni et al., 2019; Sonck et al., 2020; von Schomberg \& Hankins, 2019, for recent discussions). While the above quote from the European Commission's bioeconomy strategy already shows that consumers play an important role in the success of the transformation towards a bioeconomy, it also reveals a view of consumers that is rather passive. Yet, against the background of the long-standing debates in innovation economics mentioned above, we caution against a superficial promotion of the bioeconomy where consumers just need the right incentives for buying and using more bio-based products, thereby reducing their agency mostly to the purchase decision. Instead, the spheres and domains where consumers can become active should be made more explicit, which we will address in the subsequent section. 


\section{The Consumer as a Co-creator of a Sustainable Bioeconomy?}

The literature on (dedicated) innovation systems (Pyka, 2017; Urmetzer \& Pyka, 2021) acknowledges that (transformative) innovation processes involve multiple interconnected agents (Loorbach et al., 2020; Schlaile et al., 2017). Similarly, the social connection model of shared responsibility (Young, 2006) argues that corporations, consumers, and other actors within economic systems (e.g., investors, lobbyists, policymakers, media, and other actors in the public sphere; see also Srnka \& Schweitzer, 2000) share the power to influence unjust and unsustainable structures (e.g., Barnett et al., 2011; Schmidt, 2016, 2017, 2020; Tempels et al., 2017, 2020; Young, 2006). It is important to stress that the social connection model is a prospective concept of shared responsibility, thus focusing on future-oriented capacities of actors for changing a system for the better (Schmidt, 2016; Young, 2006). In this respect, our article follows this future-oriented notion of responsibility, which does not focus on liability or blame but rather on the degree to which different agents can become more active participants in an economy and its structural transition (see also Sonck et al., 2020, for a lucid summary of different elements of responsibility, from backward-looking to forward-looking ones). As Barnett et al. (2011) clarify:

"Young ... calls this alternative a model of shared responsibility, one in which responsibility is distributed across complex networks of causality and agency

... The advantage of the concept of shared responsibility is that it allows a more discriminating analysis of the partial ways in which actors might understand themselves to be responsible, where this in turn is not just a matter of liability or blame but is closely related to an analysis of the capacity to act" (Barnett et al., 2011, p. 8).

It should be evident by now that we do not want to create the impression that we expect consumers to always have the largest share in this systemic responsibility (see also Shove, 2010 for a related argument against an overemphasis of the roles of individuals' attitudes, behaviors, or choices). Quite to the contrary, we reject the position of a narrow variant of "consumer sovereignty" (Korthals, 2001; Persky, 1993). In fact, the responsibility of consumers must always be considered in relation to boundaries such as individual capabilities, institutional constraints, and resources (Jacobsen \& Dulsrud, 2007; Kjærnes, 2012; Schlaile et al., 2018a, 2020; Schmidt, $2016,2020)$. One cannot simply capture the agency of consumers in the bioeconomy transformation via binary categories such as "active" and "passive". While the idea that consumers can be active agents or passive participants in the (bio-) economy traditionally refers to the amount of effort that is put into each stage of the process of demanding, purchasing, and consuming, the notion of active consumers also relates to their attitudes towards novelty (Bianchi, 1998; Swann, 2009). In this context, Swann (2009) describes a continuum along different consumer types that follow various motives and interests, which can lead to a higher or lower degree of activity. From the discussion in the previous section, it should be remembered that the question whether consumers are active or passive, and to what extent, appears to be relevant when analyzing innovation processes, including systemic ones in the sense of social and economic transformations (e.g., Randelli \& Rocchi, 2017; see 


\section{Spheres of consumer responsibility ConSR-Domains}

\begin{tabular}{|l|l|}
\hline $\begin{array}{l}\text { Sphere 1: } \\
\text { Social environment } \\
\text { (Norm: Social compatibility) }\end{array}$ & $\begin{array}{l}\text { ConSR-Domain 1: } \\
\text { Responsibility for } \\
\text { information procurement }\end{array}$ \\
\hline \begin{tabular}{l|l|} 
Sphere 2: \\
Natural environment \\
(Norm: Natural compatibility)
\end{tabular} & $\begin{array}{l}\text { ConSR-Domain 2: } \\
\text { Consumer citizenship }\end{array}$ \\
\hline $\begin{array}{l}\text { ConsR-Domain 3: } \\
\text { Demand-side responsibility }\end{array}$ \\
\hline $\begin{array}{l}\text { Sphere 3: } \\
\text { Individual well-being } \\
\text { (Norm: Duty of care for oneself) }\end{array}$ & $\begin{array}{l}\text { ConsR-Domain 4: } \\
\text { besponsibility for usage decisions }\end{array}$ \\
\hline & $\begin{array}{l}\text { Critical reflection on the } \\
\text { actual purchase decision }\end{array}$ \\
\hline
\end{tabular}

Fig. 1 The "consumer responsibility territory" reprinted from Schlaile et al. (2018a, p. 566, with permission from Springer $^{\odot} 2016$ )

also the contributions in Hübner \& Schmon, 2019). Indeed, it has frequently been convincingly argued that consumers exhibit various types of power or influence on the structure of economic systems (e.g., Rommerskirchen, 2020; Schlaile et al., 2018a; Schmidt, 2016; Srnka \& Schweitzer, 2000). We thus require a differentiated and more nuanced understanding of their potential range and scope (Schlaile et al., 2018a, 2018b, 2020).

To pay tribute to this requirement of a more fine-grained classification, we take up the literature on consumer social responsibility, ${ }^{6}$ where consumers have been argued to be able to make a difference within three spheres and along five domains of what Schlaile et al. (2018a) have called the "consumer responsibility territory" (Fig. 1). This consumer responsibility territory may be understood as a potential or possibility space of consumers in the context of our article. While the three spheres are rather self-explanatory and all three of them are relevant in the context of a sustainable bioeconomy, the five domains require further elaboration:

(1) "Responsibility for information procurement". This domain includes both (a) looking for relevant information and (b) sharing this information with others.

\footnotetext{
${ }^{6}$ For example, German-speaking readers may refer to the contributions in Heidbrink and Müller (2020) for the current status of research on consumer social responsibility.
} 
Especially in the context of new products and processes, consumers frequently act under uncertainty, first and foremost regarding the foreseeability of the consequences of their consumption decisions on all three spheres. However, particularly against the backdrop of a prospective and shared social responsibility, a decisive issue is no longer the question if actors know what they do but rather to what extent they are capable of influencing their nescience (Heidbrink, 2013). In order for consumers to be able to critically reflect on the impact of their decisions they require various types of information, ideally including background data on the value chain (e.g., Schmidt, 2016), which are provided by different sources ranging from firms, labels, or the consumers themselves.

(2) "Consumer citizenship". This domain refers to a variety of actions that fall into the political realm of consumer activism (e.g., de Tavernier, 2012; Müller, 2020; Schrader, 2007; see also Kallhoff, 2016 for a critical discussion). Examples of actions typically associated with political consumerism include boycotts, "buycotts" (i.e., deliberate purchase), various discursive actions, and lifestyle choices (e.g., Micheletti et al., 2012). Moreover, there is a broad literature on the potential of politicizing consumption revolving around consumers that actively seek to become agents for sustainable change through their actions (e.g., Lamla \& Neckel, 2006; Røpke, 2013; WBGU, 2011, Sect. 6.3.3), which explicitly goes beyond boycotts or purchasing more climate-friendly products.

(3) "Demand-side responsibility". The third domain of demand-side responsibility can be further specified into (a) "pre-purchase decisions", (b) "consumption as voting", and (c) the "critical reflection on the actual purchase decision". Prepurchase decisions (a) are an umbrella term for consumers' active participation in the value creation process especially prior to purchase, for example, by means of "co-production" and "co-creation of value" (e.g., Etgar, 2008; Hoffmann, 2007; Martínez-Cañas et al., 2016; Senge \& Carstedt, 2003; Vargo et al., 2020) or "user/consumer innovation" (e.g., Grabher \& Ibert, 2018; Grabher et al., 2008; Roberts et al., 2014; von Hippel et al., 2011). Consumption as voting (b) could be regarded as another particular domain of political consumerism: Not too different from a ballot, consumers can exert influence by being a force of selection (e.g., Dickinson \& Carsky, 2005; Moraes et al., 2011; Shaw et al., 2006). Finally, the critical reflection on the actual purchase decision $(c)$ includes assessing potential consequences, alternatives (in terms of quantity and characteristics of purchased goods and services), critically reflecting on one's needs, and eventually changing one's purchasing behavior (e.g., Heidbrink \& Schmidt, 2011; Schmidt, 2016).

(4) "Responsibility for usage" and (5) "responsible disposal" are two rather selfexplanatory domains but nonetheless highly relevant as much research on consumer responsibility tends to revolve around the purchasing decision. However, the subsequent processes of actually consuming, that is, using a product or service and disposing of what is left at the end of this process are often at least as important as the purchase decision (e.g., Lee et al., 2019, on the issue of responsible recycling) - especially in the context of a sustainable (and potentially even circular) bioeconomy. Using and disposing of goods and services in 
a responsible way generally saves resources and avoids unnecessary waste (see also Heidbrink \& Schmidt, 2011, on a related discussion).

In the following section, we use the above category of active vs. passive consumers in combination with the five domains as a template for coding the articles in our literature review. However, we caution against regarding the following analysis as an investigation of moral responsibility (as most articles do not explicitly address ethical issues) but rather as the degree to which a publication captures the different roles or activities of consumers in the bioeconomy (along the continuum of possibilities within their consumer responsibility territory).

\section{Systematic Literature Review}

\section{Method and Data}

To investigate how consumers are depicted in the bioeconomy literature, we present a systematic literature review in a manner informed by Okoli (2015), Tranfield et al. (2003), and Palmatier et al. (2018). The literature review was done following the PRISMA (Preferred Reporting Items for Systematic Reviews and Meta-Analyses) framework (Moher et al., 2009). The steps are depicted in Fig. 2. (Identification, Screening, Eligibility, Included). The relevant literature was analyzed by following the procedure of Krippendorff (2004) in unitizing, sampling, and coding.

Step 1 (identification) was a search on Scopus combining the search terms "consum*" OR "demand side" OR "demand driven" OR "procurement" AND "bio economy" OR "bioeconomy" OR "bio-based economy" in the title-abstract-keywords fields. ${ }^{7}$ The first part of the search string covers different terms referring to consumers and, respectively, the demand side they represent. The second part covers bioeconomy and the synonymously used term bio-based economy in its variant forms of spelling. The search on Scopus resulted in 282 publications.

In step 2 (screening/eligibility), we analyzed those 282 publications regarding their relevance for the analysis at hand by reading the abstract. In several cases, additionally scanning through the full text of a publication was necessary to allow an informed decision whether to include a publication or not. The publication furthermore had to be available on 7 November 2019 to be included in the review. Step 2 lead to the exclusion of 188 publications, leaving an initial selection of 94 publications.

In the third step, documents were checked for inclusion in the final sample. The detailed analyses of the 94 publications lead to the exclusion of 20 papers due to a lack of relevance, leading to a final sample of 74 publications.

We furthermore scrutinized the reference lists to check for further relevant publications ("backward citation snowballing"), which did, however, not result in

\footnotetext{
7 The exact search query was: TITLE-ABS-KEY ((consum* OR ("demand side") OR ("demand driven") OR procurement) AND ("bio economy" OR "bioeconomy" OR "bio-based economy")).
} 


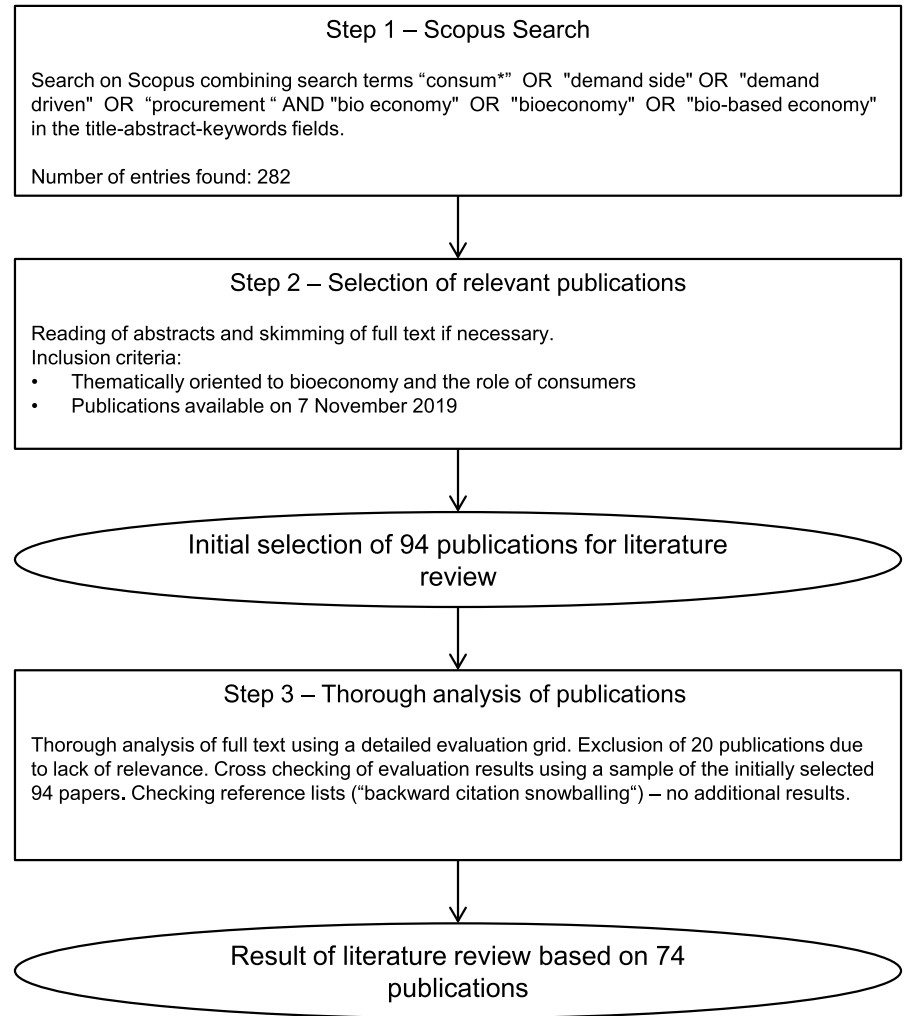

Fig. 2 Process of our literature review

the inclusion of additional publications. This final sample of 74 publications was thoroughly analyzed using qualitative content analysis (Mayring, 2014, 2015). We coded the content using deductive category assignment (Mayring, 2014), using a detailed coding scheme, grounded on the above theoretical considerations. The detailed coding scheme is shown in Table 1. It consists of two evaluation categories, namely category A: Active or passive role of consumers, and category $B$ : Domains of consumer responsibility, which is divided in five sub-categories representing the different domains described above in the previous section. To assess the inter-rater reliability, a small number of additional data must be concurrently, but independently, coded by all coders. There is no general consensus on the optimal amount of data needed to credibly assess the inter-rater reliability (Campbell et al., 2013) but 10-25\% are assumed to be sufficient (O'Connor \& Joffe, 2020). We decide to take 8 randomly selected articles, which is equivalent to around $10 \%$ of the reduced sample. Based on this sample, we calculated Fleiss' Kappa with a statistically significant value of 0.467 . According to Landis and Koch (1977), this can be considered as "moderate agreement". Taking into account the latent characteristic of the rated items, the relatively high number of 


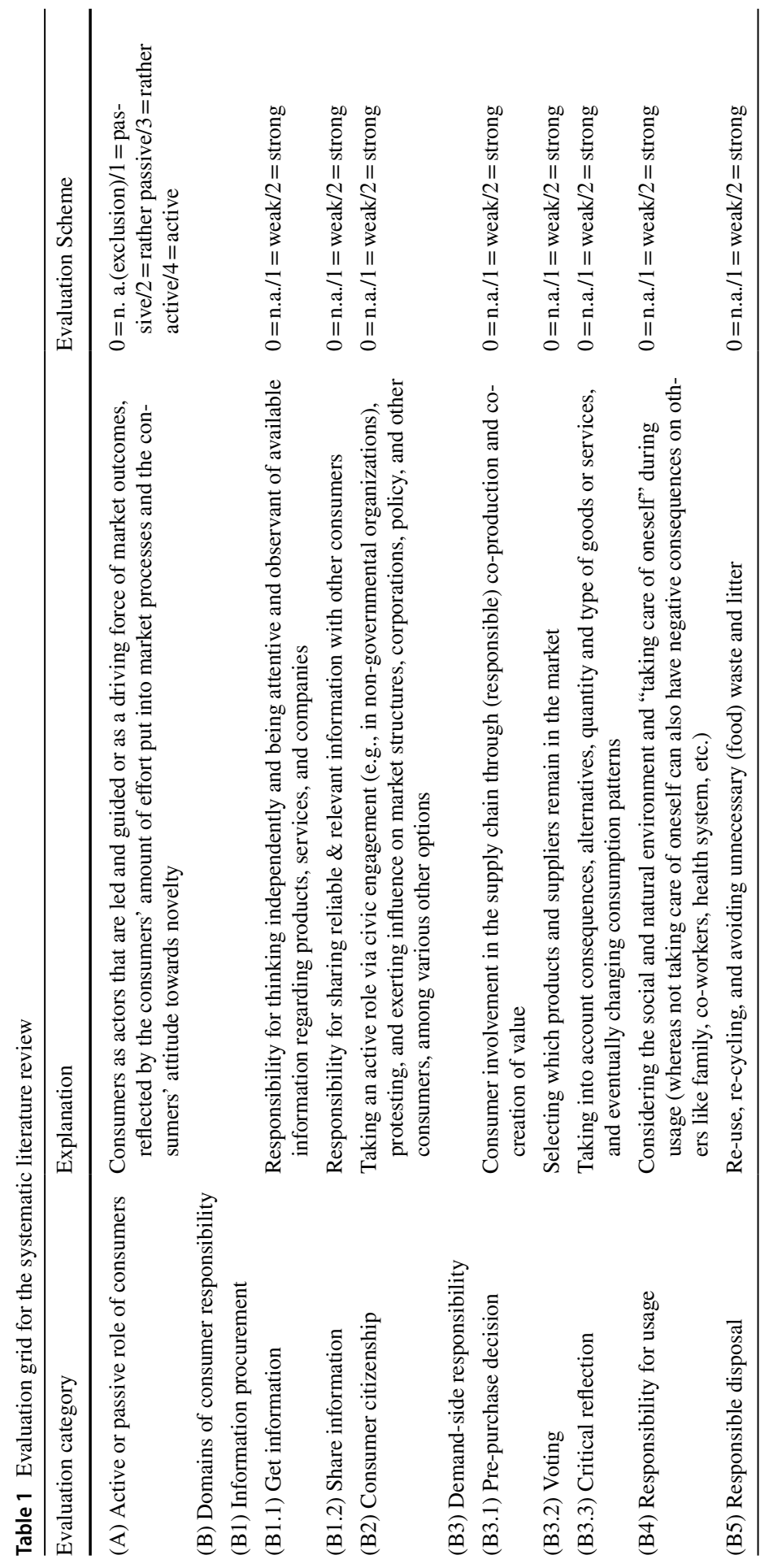




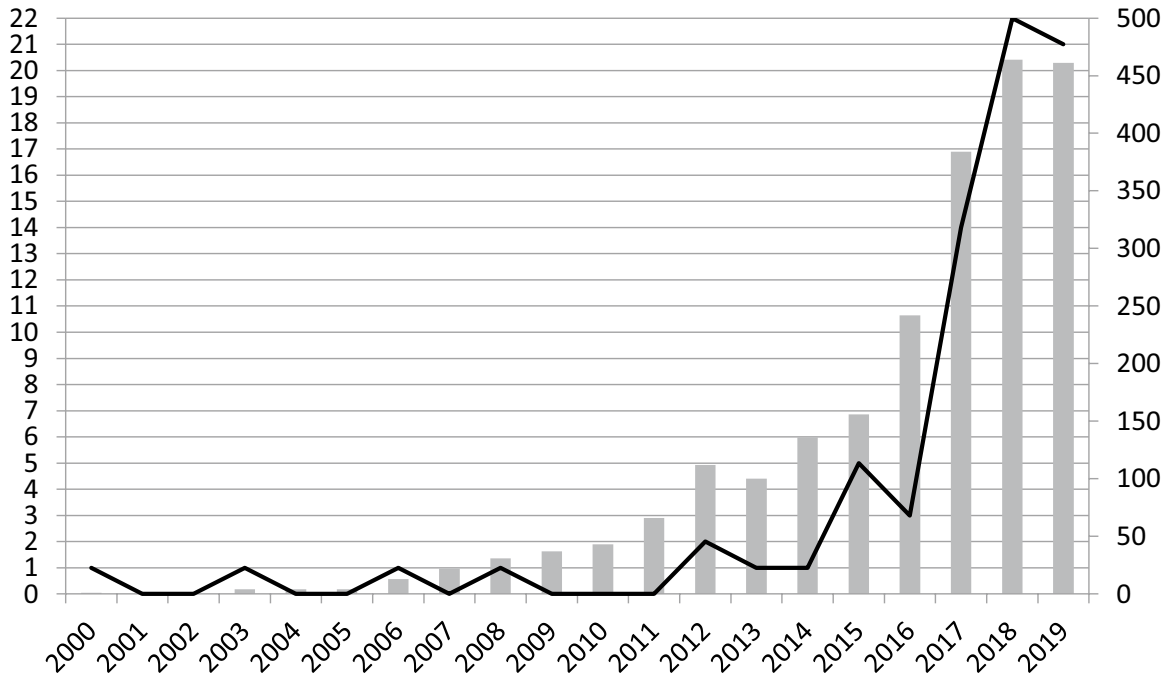

Fig. 3 Distribution of articles included in literature review according to year of publication. Left axis: number of publications considering both consumer and bioeconomy. Right axis: total number of publications in the field of bioeconomy

categories (in total 8 (sub-)domains) and the comparably large number of four coders, we consider this value to be sufficient to allow for an aggregation and comparison of the different ratings. ${ }^{8}$

The 74 publications are composed of 64 journal articles, 8 book chapters, and 2 conference papers. Figure 3 shows the spread of publications included in the literature review based on their year of publication. The figure illustrates that the role of consumers in the bioeconomy is receiving growing attention, in line with an overall increase of papers addressing bioeconomy. The oldest publication stems from the year 2000, while most of the others have been published since 2017 .

The journal articles stem from 41 different journals, covering a broad thematic range including agriculture, economics, forestry research, technology transfer, environmental research, innovation policy, sustainability research, and others (see references marked with $*$ in the reference list for a complete list of publications included in the final selection). Most of the journals are represented with only one article, showing the heterogeneity of interest in this topic.

\section{Findings}

In this section, we describe the results of the content analysis based on the abovementioned evaluation grid as shown in Table 1. Figure 4 displays the findings for

\footnotetext{
${ }^{8}$ Subjects $=80 ;$ Raters $=4$ Kappa $=0.467 ; \mathrm{z}=12.7 ; \mathrm{p}$-value $=0$.
} 


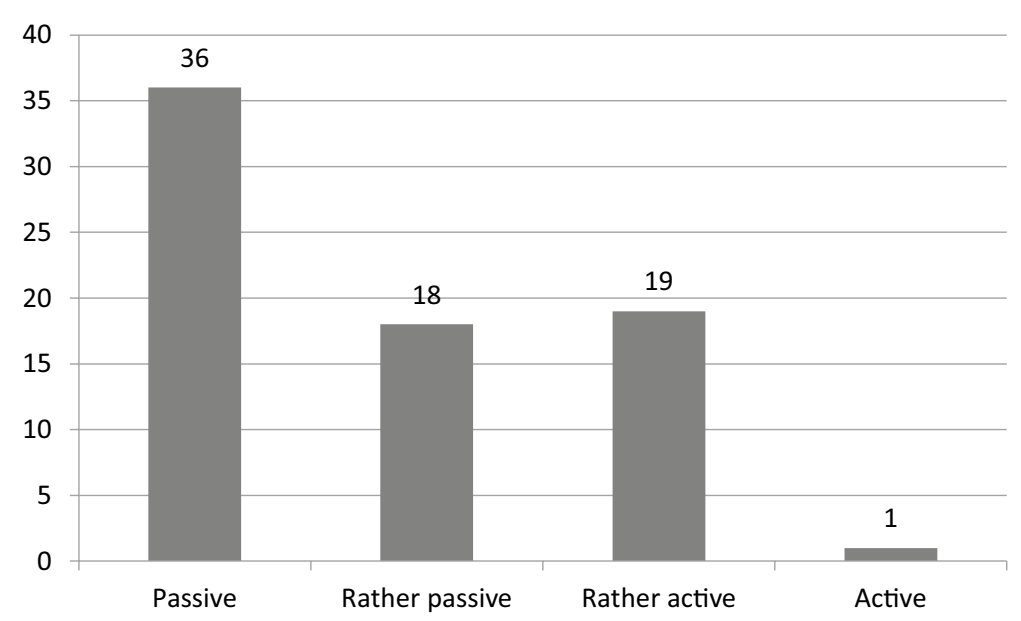

Fig. 4 Allocation of papers along evaluation category A: Active or passive role of consumers

evaluation category A: Active or passive role of consumers. For this category, the publications were classified according to their overall depiction of the role of consumers as passive, rather passive, rather active, or active. Publications that did not address any consumers partaking in the economic process (i.e., neither active nor passive) were excluded due to the centrality of this aspect for our analysis (hence the exclusion of 20 papers in step 3 of the literature review process).

In the remaining 74 publications, the consumers' role is mostly described as passive (49\% of publications) or rather passive (24\%). Roughly a fourth of the papers $(27 \%)$ depict the consumers as rather active or active. An example of a passive role of consumers can be found in Jarre et al. (2020), where the consumers' role regarding the success of new biobased products is only relevant in the sense that the awareness of consumers of these new products has to be actively raised by the producers. Dobrowolski et al. (2017) is an example of a rather passive role of consumers as they illustrate at least some feedback from consumers, which has a (limited) influence on the development of new biobased products. An example of a rather active role of consumers can be found in Grundel and Dahlström (2016) who state that the involvement of consumers in innovation processes is necessary for the transformation towards a sustainable bioeconomy. The one publication in the sample depicting an active role of consumers (Winkler et al., 2019) describes how consumers actively change not only consumption but also production patterns in a bioeconomy.

Figure 5 shows the assessment of the 74 publications regarding the elements of evaluation category B: Domains of consumer responsibility. For each domain or sub-domain, the publications were categorized according to their account of the corresponding element. If an element was not addressed at all, the publication yielded 0 for not addressed. If consumers' roles were described in a way that a (sub-)domain was covered, the corresponding publication was coded 1 for weak coverage and 2 for strong coverage. 


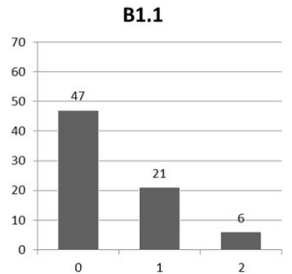

B3.2

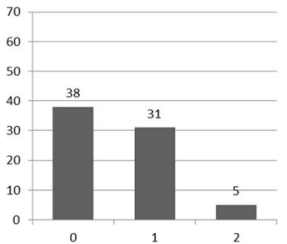

B1.2

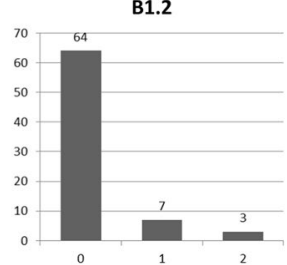

B3.3

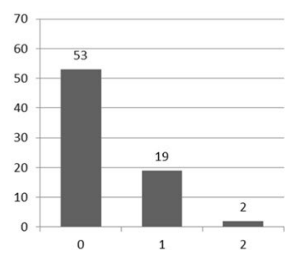

B2

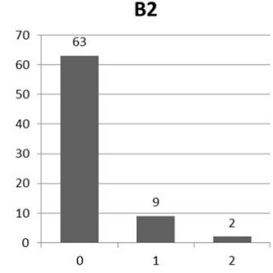

B4

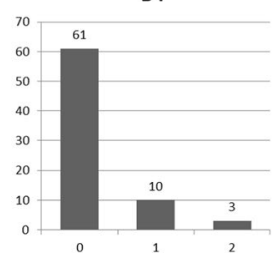

B3.1

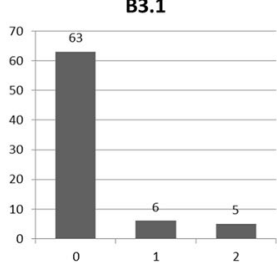

B5

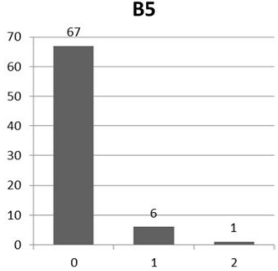

Fig. 5 Allocation of papers along the elements of evaluation category B: Domains of consumer responsibility. Legend: B1.1 = Information procurement - get information; B1.2=Information procurementshare information; B2=Consumer citizenship; B3.1=Demand-side responsibility-pre-purchase decision; B3.2=Demand-side responsibility—voting; B3.3 = Demand-side responsibility—critical reflection; B4 = Responsibility for usage; B5 = Responsible disposal; $0=$ not addressed; $1=$ weak; 2 = strong

The overall picture shows that the different (sub-)domains are addressed to a varying extent with most of the elements being addressed only by a minority of the publications. The aspect captured by far the most is B3.2: consumption as voting, which is addressed by 36 publications. In contrast to this, we see that B5: responsible disposal is considered by only seven publications.

To get a more in-depth understanding of how the bioeconomy literature perceives of consumers, we will now give examples from the literature and describe the appraisal regarding the eight elements. In sum, 27 of the 74 publications cover the issue of responsibility for information procurement $(B 1)$, reflecting about aspects such as the growing information demand regarding biobased products in general (Brătucu et al., 2019; Soetaert \& Vandamme, 2006), labeling as means for information procurement (Egenolf \& Bringezu, 2019; García et al., 2018; Ladu \& Blind, 2017), social learning (Grundel \& Dahlström, 2016), and others. Among those publications, the aspect of getting information (B1.1) is addressed by all of these 27 publications (with six publications putting a strong weight on this aspect and 21 publications attributing less weight to it). In comparison, sharing the information $(B 1.2)$ is addressed by only ten publications.

The issue of consumer citizenship (B2) is raised by only 11 publications, two of which put a high weight on this aspect. Publications reflecting on this issue address, for example, the forming of consumer movements to influence bioeconomy policies (Marsden \& Farioli, 2015; Zilberman et al., 2015), or the role of consumer networks in innovation processes of the bioeconomy (Pyka \& Prettner, 2018).

The domain B3: demand-side responsibility is divided into three subdomains: pre-purchase decisions (B3.1), consumption as voting (B3.2), and critical reflection on the actual purchase decision (B3.3). Of the 74 publications, 47 consider at least one of these subdomains with eleven publications addressing B3.1, 36 addressing 
B3.2 and 21 publications addressing B3.3. Of those 47 publications, 32 focus on only one of these subdomains and six publications consider all three of them.

Regarding consumers' pre-purchase decisions (B3.1), the literature covers aspects such as the involvement of consumers as co-creators in value chains and development processes of biobased products and services (Kristinsson \& Jörundsdóttir, 2019; Toppinen et al., 2017), or the introduction of practices and norms for co-creation processes (Kurppa, 2016).

The aspect of consumption as voting (B3.2) is the domain most frequently represented in the publications. This is quite unsurprising, as selecting which products and suppliers remain in the market is the most straightforward channel of consumers' influence. Five publications make a strong case for consumption as voting (B3.2), while another 31 publications ascribe at least some importance to this aspect of consumer activity, which means that almost half of the publications in our overall sample cover this topic. Those papers reflect on issues such as the consumers' attitudes in selecting products (Bennich et al., 2018; Duchesne \& Wetzel, 2003), or the diverse interests of consumers (e.g., Hagemann et al., 2016), while several others address a growing demand of consumers for more sustainable (e.g., environmentally friendly or socially fair) bio-based products (Hertel et al., 2013; Jong et al., 2012; Korhonen et al., 2020; Toppinen et al., 2017).

The sub-domain B3.3: critical reflection is found in 21 publications, however, with only two publications giving it a strong weight. Regarding this element, the literature contemplates, for instance, consumers' consideration of the whole life cycle of biobased products (Egenolf \& Bringezu, 2019), thorough reflection of environmental impacts (Vatamanescu et al., 2018), or the consideration of higher costs for biobased products as investment into the future (Hagemann et al., 2016).

A domain that only receives relatively little attention is responsibility for usage (B4) with in total 13 publications addressing the issue and only three putting a strong emphasis on this domain. The publications address issues such as the link between the usage of biobased products, physical health, and biodiversity (Schutter et al., 2019), or the shift in consumers' perception regarding usage and ownership (Barčić et al., 2019).

Finally, the domain of responsible disposal (B5) is the least addressed, with only one publication (Pätäri et al., 2017) giving this aspect a high weight, and six publications giving it some weight, which means that less than $10 \%$ of the publications address this domain at all. Issues addressed are, for example, new forms of consumption such as collaborative consumption, which can have positive effects on the amount of waste produced (Barčić et al., 2019; Imbert, 2017), or disposal as the least preferred end-of-life option consumers should choose, yet acknowledging technical and other barriers to re-use and re-cycle activities (Escobar et al., 2018; Korhonen et al., 2020).

In addition to the elaboration above, an even more detailed insight into the representation of consumers' scope of action in the bioeconomy literature can be gained by scrutinizing the links between the different (sub-)domains. Arguably, for capturing the consumers' scope of action in a specific domain it may be justified to do so in an isolated manner, that is, without considering the connections of that domain with others. However, at the same time, given our more systemic understanding of 


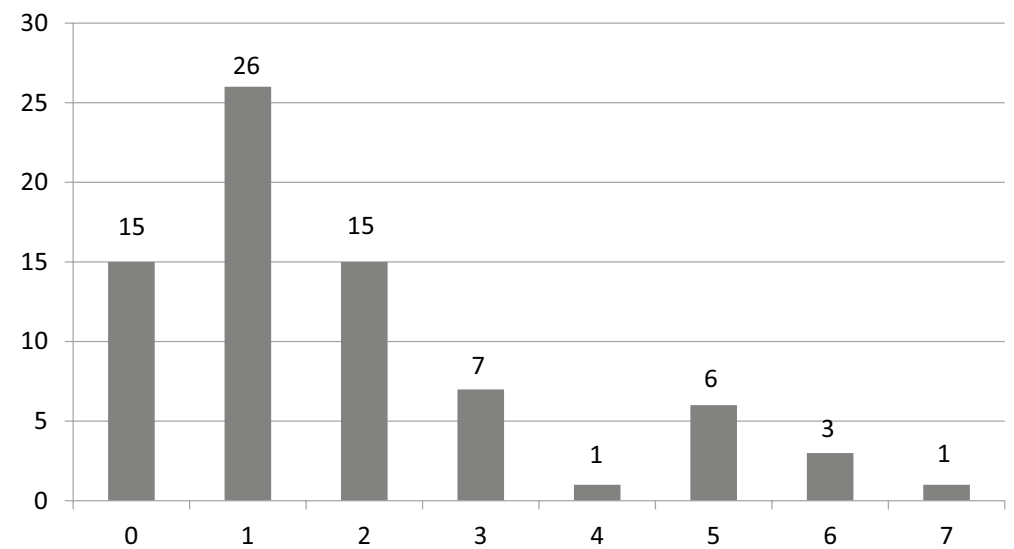

Fig. 6 Frequency distributions of domains mentioned per publication. The 15 papers not mentioning a domain still attributed at least a passive role to the consumer (category A) but did not allow for an unambiguous attribution to a specific domain (category B)

transitions and economic processes (including innovation), we would assume that an isolated or too focused discussion neglects potential interdependences between the domains and may present a myopic and reductionist perspective.

Our analysis reveals major differences in terms of interconnectedness among the different (sub-)domains (see Fig. 6 and Tables 2 and 3), that is, how many domains are treated by a publication at the same time and which domains are dealt with jointly. Figure 6 shows that the majority of publications tackle only a small number of elements while a few consider the role of the consumer alongside different (sub-)domains, thereby taking a more comprehensive perspective, such as Pätäri et al. (2017), who explicitly see consumption as a process with many phases also including post-use behavior. Only one publication (Grundel \& Dahlström, 2016) covers seven (sub-)domains and none of the publications addresses all of the eight (sub-)domains. Table 2 gives an overview on how many papers that address a specific domain also consider other domains and shows the average number of other domains mentioned. An even more granular picture of the domains' co-occurrence within the reviewed publications is provided in Table 3.

To derive the results presented in Table 3, we first count the total number of publications that address a particular domain (black diagonal cells). We then counted for any pair of domains $(i, j$ with $i \neq j)$ the number of publications that address both domains $X_{i, j}$ (absolute numbers in brackets). Based on this, we computed the relative occurrence of a domain $j$ (columns) for domain $i$ (rows) by dividing the number of publications that address these domains $\left(X_{i, j}\right)$ with the total number of publications that address domain $i$ (percentages in Table 3 ). So, for example, by dividing the total number of publications that address both domains $B 1.1$ and $B 1.2$ with the total number of publications that address $B 1.1$, we see that approx. $37 \%$ of all publications that address B1.1 also consider B1.2. In contrast, the total number of publications that address both domains $B 1.1$ and $B 1.2$ divided by the total number of publications that address B1.2 shows us that 


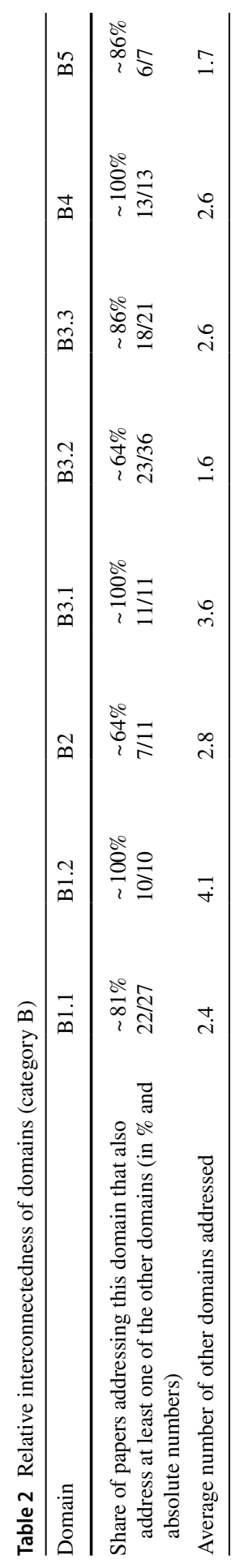


Table 3 Directed and weighted co-occurrence matrix of domains in publications

\begin{tabular}{|c|cccccccc|}
\cline { 2 - 10 } \multicolumn{1}{c|}{} & B1.1 & B1.2 & B2 & B3.1 & B3.2 & B3.3 & B4 & B5 \\
\hline B1.1 & 27 & $37 \%(10)$ & $26 \%(7)$ & $33 \%(9)$ & $59 \%(16)$ & $56 \%(15)$ & $22 \%(6)$ & $4 \%(1)$ \\
B1.2 & $100 \%(10)$ & 10 & $60 \%(6)$ & $60 \%(6)$ & $70 \%(7)$ & $90 \%(9)$ & $30 \%(3)$ & $0 \%(0)$ \\
B2 & $64 \%(7)$ & $55 \%(6)$ & 11 & $45 \%(5)$ & $45 \%(5)$ & $45 \%(5)$ & $27 \%(3)$ & $0 \%(0)$ \\
B3.1 & $82 \%(9)$ & $55 \%(6)$ & $45 \%(5)$ & 11 & $73 \%(8)$ & $64 \%(7)$ & $36 \%(4)$ & $9 \%(1)$ \\
B3.2 & $44 \%(16)$ & $19 \%(7)$ & $14 \%(5)$ & $22 \%(8)$ & 36 & $33 \%(12)$ & $22 \%(8)$ & $8 \%(3)$ \\
B3.3 & $71 \%(15)$ & $43 \%(9)$ & $24 \%(5)$ & $33 \%(7)$ & $57 \%(12)$ & 21 & $24 \%(5)$ & $10 \%(2)$ \\
B4 & $46 \%(6)$ & $23 \%(3)$ & $23 \%(3)$ & $31 \%(4)$ & $62 \%(8)$ & $38 \%(5)$ & 13 & $38 \%(5)$ \\
B5 & $14 \%(1)$ & $0 \%(0)$ & $0 \%(0)$ & $14 \%(1)$ & $43 \%(3)$ & $29 \%(2)$ & $71 \%(6)$ & 7 \\
\hline
\end{tabular}

all publications (100\%) that address $B 1.2$ also consider B1.1. This reveals some major discrepancies and a structural asymmetry in the mutual consideration of the domains.

Regarding the issue of responsibility for information procurement (B1), $81 \%$ of the papers addressing getting information (B1.1) also address one or more of the other domains, with an average of 2.4 other domains being addressed. As shown in the first row of Table 3, the other domain most frequently covered by those papers addressing B1.1 is consumption as voting (B3.2) (i.e., $59 \%$ of the papers addressing $B 1.1$ are also concerned with B3.2), closely followed by $B 3.3$ (with $56 \%$ ). All those papers speaking about sharing information (B1.2) also address one or more of the other domains, with on average 4.1 other domains being discussed, which is the highest value among all domains. Rather unsurprisingly, all papers dealing with $B 1.2$ also approach B1.1. Interestingly, $90 \%$ of the papers addressing $B 1.2$ also treat the topic of critical reflection (B3.3).

Only $64 \%$ of the papers addressing consumer citizenship (B2) also look at one or more other domain, with on average 2.8 other domains being addressed. Most frequently, $B 1.1$ is also addressed (64\%), followed by $B 1.2(55 \%)$.

Looking more closely at domain B3: demand-side responsibility, we see that all papers addressing $B 3.1$ (pre-purchasing decision) also pay attention to one or more of the other domains (on average 3.6 others). Of all domains covered together with B3.1, getting information (B1.1) is the most common one (82\%), followed by B3.2 and B3.3. Only $64 \%$ of the papers addressing consumption as voting (B3.2) also touch upon other domains, with on average only 1.6 other domains being covered. Again, B1.1 is the domain most frequently addressed (44\%), followed by B3.3. Interestingly, there is no strong connection to B3.1 in this direction. From the papers covering critical reflection (B3.3), 86\% also attend to one or more of the other domains (on average 2.6 other domains). The strongest link is again to $B 1.1$ (71\%) followed by $B 3.2(57 \%)$. Yet again, there is no particularly strong connection to $B 3.1$ in this direction.

All papers covering the domain of responsibility for usage (B4) also address one or more other domain, with on average 2.6 other domains being treated by these publications as well. The strongest link exists to $B 3.2$ (62\%) followed by $B 1.1$ (46\%). 
Finally, six of the seven publications speaking about responsible disposal (B5) also deal with one or more other domain (on average 1.7 other domains). Here, the most prominent link exists to $B 4(71 \%)$, followed by $B 3.2(43 \%)$.

To summarize, our results present a detailed picture of the different weight and interdependence of the domains as addressed in the contemporary bioeconomy literature. In the following section, we will discuss selected findings against the background of the overarching theoretical debate.

\section{Discussion}

Starting from the previously undocumented and thus merely anecdotal suspicion that the scientific bioeconomy literature could be biased towards what Blok (2020) calls the techno-economic paradigm of innovation (which regards novelty creation as mainly driven by new technologies that are introduced into the market by the "supply side"), we have taken up the task of looking more closely and systematically into the way consumers have been treated in the contemporary bioeconomy literature. Our analysis has followed established procedures for systematic reviews and qualitative text analysis, and we proposed and applied a novel coding scheme to move beyond dichotomous representations of merely active vs. passive consumers. By doing so, our results contribute to the literature not only by presenting the current state of the art of research on consumers in the context of the bioeconomy in a detailed manner but also by developing a more nuanced and theoretically wellfounded analytical approach to depicting consumer activity in economic systems.

So, what have we gained? First and foremost, our results clearly indicate that most bioeconomy-related publications indeed focus on other issues than consumers. ${ }^{9}$ Interestingly, in the subset of the bioeconomy literature that made up our final sample (i.e., the 74 publications marked with $*$ in the references), consumers tend to be considered in a mostly passive way. Moreover, our analysis reveals that the scientific bioeconomy literature, thus far, focuses mainly on the more "traditional" domains through which consumers have been argued to contribute to economic change, that is, through consumption as voting (B3.2; occurring in 36 papers) and thanks to information procurement-especially getting information (B1.1; occurring in 27 papers). In this regard, our review already supports the aforementioned bias towards reducing the consumer's sphere of influence mostly to the adoption (or refusal) of new bio-based products and processes.

In the context of the transition towards a sustainable bioeconomy, however, this focus should be questioned. Yet, it is likely that some bioeconomy scholars will argue that the current focus of the literature is fully justified-especially if they were to view the bioeconomy from the lenses of industrial biotechnology or efficient biomass utilization (which only represent a "weak sustainability"

\footnotetext{
${ }^{9}$ For the timeframe considered in our analysis, this means that only roughly $3.3 \%$ of the bioeconomy publications found with the Scopus search string TITLE-ABS-KEY ( "bio economy" OR "bioeconomy" OR "bio-based economy") address consumers.
} 
approach, though; cf. Vivien et al., 2019). Indeed, if one adheres to a technoeconomic innovation paradigm (Blok, 2020) that focuses solely on the necessary technological advances that facilitate the transformation towards a bioeconomy, then the consumers' scope of action may-at most-be viewed as the collective "voting" for more or less "responsible" technological innovations. However, as argued above in our "Why the bioeconomy is more than a supply-side endeavor" section, the transition towards a sustainable bioeconomy goes way beyond market acceptance and diffusion of novel and "more efficient" biotechnological innovations.

In this context, it is also worthwhile to have a closer look at our findings regarding the treatment of the actual consumption (i.e., usage of goods, services, energy, resources, etc., and the disposal of what is left at the end of this process) after the purchase decision. We observe in the literature a relatively low consideration of the domains of usage (B4; occurring in 13 papers, of which it is highlighted in 3) and disposal (B5; occurring in 7 papers, of which it is highlighted in 1). Especially in the context of a sustainable bioeconomy, it is noteworthy that responsible disposal (B5) is only rarely addressed (in less than $10 \%$ of the publications of our final sample) and that this domain has not been covered in connection to B1.2 and B2 at all. Apparently, in the current bioeconomy discourse, this domain is treated as a rather individual one with no obvious collective dimension. It is quite surprising that the topic of responsible use and disposal by consumers has not received much attention compared to the other domains, especially since circular economy approaches and waste or residuals at the end of the product life cycle are of central importance in a bioeconomy. The potential superiority of the environmental performance of bioplastics as compared to their conventional fossil-based counterparts, for instance, has been found to be strongly dependent on their 'end of life'. Studies have shown that the ways plastics are used and disposed of are critical for the evaluation of the sustainability of plastics (European Commission, 2018b). Waste separation, deposit schemes, the avoidance of littering, or reuse and repair (Bertling et al., 2018) are not only matters of design and effective waste management, but also depend on the individual decisions of the person taking possession of the product (Minelgaitė \& Liobikienè, 2019).

More generally, it should be remembered that consumers' motivations, behaviors, lifestyles, and daily routines have frequently been argued to be relevant especially for the success (or failure) of sustainable development (Heidbrink \& Schmidt, 2011; Jaeger-Erben et al., 2015; López Davis et al., 2017; McCormick et al., 2016), also in the context of a sustainable bioeconomy (Otto et al., 2020, 2021). At the same time, however, there have been important arguments against over-emphasizing the roles of individual consumers without sufficient acknowledgment of their embeddedness within the greater innovation or socio-technical systems (Shove, 2010), different institutional or cultural background, budget and other constraints, access to knowledge and information, and many other capabilities (Gjerris et al., 2016; Grunwald, 2010, 2012; Jacobsen \& Dulsrud, 2007; Kjærnes, 2012; Schlaile et al., 2018a). Our findings suggest that the bioeconomy literature still has much to gain from taking up these relevant debates, especially to avoid falling for the lure of a rather one-sided techno-economic paradigm. 
Another insight from our systematic review is that getting information seems to be acknowledged as relevant in the bioeconomy literature also in the context of the other domains (since publications discussing other domains also frequently address B1.1). For example, sharing information (B1.2) only appears together with B1.1 (getting information). Indeed, getting information has often been argued to be a prerequisite for any kind of consumer activity, especially responsible consumption (Schmidt, 2016; Srnka \& Schweitzer, 2000). ${ }^{10}$ Moreover, the different interconnections we revealed between the domains in the literature can be used as a starting point for further inquiries into necessary and sufficient conditions for consumers to contribute to the transition towards a sustainable bioeconomy. For example, the sharing of information (B1.2) appears to be the most salient aspect also in the context of many of the other domains. Notably, both consumer citizenship (B2) and all the sub-domains of demand-side responsibility (B3) are strongly interconnected with both sub-domains of information procurement $(B 1)$. The example of bioplastics introduced before illustrates how conducive a holistic consideration of the various domains of consumer responsibility is especially in the context of a transition to a sustainable bioeconomy: It is not sufficient for the responsible "bio consumer" to just choose the bio-based plastic product. The way we consume is of considerable importance for the success or the failure of the establishment of a truly sustainable bioeconomy. A first step can be the inquiry into the type of bio-based material and the sharing of this information with peers (B1: Information procurement) (e.g., regarding the origin and related carbon footprint of the raw material; cf. European Commission 2018b). A second step can be active engagement for the communal waste management (B2: Consumer citizenship) or the critical reflection of the own demand by also taking into consideration alternatives (B3: Demand-side responsibility). Another step involves critical reflection of the decisions regarding use ( $B 4$ : Responsibility of usage) and disposal (B5: Responsibility of disposal) (see above).

Considering these insights, a few limitations must be acknowledged. First, it is important to note that although we build upon the domains identified in the consumer responsibility literature, our review cannot reveal the exact roles and responsibilities consumers may or may not have in the structural transition towards a sustainable bioeconomy. Nonetheless, our results and the theoretical discussion presented above have pointed towards several aspects that may be under-researched and should be taken up in further conceptual and empirical bioeconomy research. Second, our qualitative review has the methodological limitation that it relies heavily on subjective components that are prone to different interpretations by the individual authors, especially against the backdrop of the complexity of the consumer responsibility domains. Regarding the review process, we thus acknowledge that the interrater reliability has to be considered as representing "moderate agreement" (Landis $\&$ Koch, 1977) between the four coders. Third, having coded a paper as strongly

\footnotetext{
${ }_{10}$ Notably, of the 27 publications addressing B1.1, only 10 address B1.2. Yet, 16 address consumption as voting (B3.2) and 15 cover critical reflection (B3.3). Hence, one could get the impression that a central aspect of consumer action in a bioeconomy is seen in getting information about which products to buy, purchasing them, and reflecting upon this decision.
} 
addressing a particular aspect does not necessarily reflect the paper's overall focus (e.g., consumers may have been positioned in an active way but do not play a major role for the research focus of the respective paper). Fourth, we acknowledge that we have not focused on the bioeconomy paradigm predominant in the papers (e.g., if the papers explicitly or implicitly represent a focus on biomass utilization, industrial biotechnology, or an ecological economy more broadly as described by Vivien et al., 2019). It may thus be interesting for future studies to take up the question in which ways the representation of the consumers differs in the various perspectives on the bioeconomy.

\section{Conclusion}

The bioeconomy in its various facets has been promoted both by policymakers and scientists especially due to its various promises of positive impacts on society, economy, and the environment. We share the widely held view that the bioeconomy has the potential to contribute to sustainability transitions but that it will not automatically lead to more sustainable processes of production and consumption (e.g., Székács, 2017). We build upon the view that the bioeconomy involves (responsible) innovation processes on various scales beyond (but including) new technologies. The literature on innovation economics and consumer responsibility provides foundational arguments for regarding consumers as potentially active agents. This means that they are not merely passive participants within the structural transition towards a sustainable bioeconomy but share responsibility with other actors in the system. This argument provides the theoretical starting point for our systematic literature review that fathoms how the consumers' scope of action is represented in the scientific bioeconomy literature. With the findings of our review, we contribute to the literature on multiple ways: First, our paper provides a starting point for further inquiry as this is the first systematic review of the consumers' scope of action in the context of a (sustainable) bioeconomy. Second, we propose and apply a novel coding scheme to evaluate whether consumers are treated as active or passive and specify the consumers' sphere of influence along five domains (or, eight sub-domains) known from the literature on consumer social responsibility (e.g., Schlaile et al., 2018a). Third, our results have shown that the consumer has been treated as a mostly passive entity within the bioeconomy literature, which is at least questionable against the backdrop of our theoretical considerations and should thus be taken up in future empirical and conceptual research (e.g., especially considering the increasingly blurred boundaries between consumers, producers, and citizens). Fourth, we have revealed various interesting interconnections but also several missing links between the different domains that can also serve as a basis for future studies. Finally, and quite generally, we conclude that our article has shown that there is a promising field of scientific inquiry into the complexity and interdependence of roles, shared responsibilities, and distributed agency of consumers in the context of a sustainable bioeconomy. At the same time, this article should also be read as an appeal to bioeconomy policymakers to resist the lure of the dominant technoeconomic paradigm of innovation. 
Acknowledgements We have benefited from presenting an earlier version of this article at our international workshop on The Normative Dimension of Transformations towards a Sustainable Bioeconomy, held at the University of Hohenheim in Stuttgart, September 13-14, 2019. We are grateful for helpful feedback, suggestions, and comments from the participants of this workshop as well as the comments and suggestions from two anonymous reviewers and to the Journal of Agricultural and Environmental Ethics' former editor in chief, Jeffrey Burkhardt, for facilitating our special issue.

Funding Open Access funding enabled and organized by Projekt DEAL. This work has received no specific grant from public or private funding sources, but we would like to gratefully acknowledge funding for our workshop, where this work was presented, from the German Research Foundation (project number 429014130), Universitätsbund Hohenheim e.V., and the Ministry of Science, Research and the Arts Baden-Württemberg. Matthias Müller gratefully acknowledges partial funding through the project V4InnovatE by the Federal Ministry of Education and Research (Grant number 03EI5206B). Michael Schlaile gratefully acknowedges partial funding from the Volkswagen Foundation through the project "Changing the Foundations of Economic Thought in the Midst of Crisis - How Economic Actors Create New Imagined Futures for Sustainable Economies" (Grant number 99 116).

\section{Declarations}

Conflict of interest The authors declare that they have no conflict of interest.

Open Access This article is licensed under a Creative Commons Attribution 4.0 International License, which permits use, sharing, adaptation, distribution and reproduction in any medium or format, as long as you give appropriate credit to the original author(s) and the source, provide a link to the Creative Commons licence, and indicate if changes were made. The images or other third party material in this article are included in the article's Creative Commons licence, unless indicated otherwise in a credit line to the material. If material is not included in the article's Creative Commons licence and your intended use is not permitted by statutory regulation or exceeds the permitted use, you will need to obtain permission directly from the copyright holder. To view a copy of this licence, visit http://creativecommons.org/licen ses/by/4.0/.

\section{References}

Andersen, E. S. (2007). Innovation and demand. In H. Hanusch \& A. Pyka (Eds.), Elgar companion to neo-Schumpeterian economics (pp. 754-765). Edward Elgar.

*Andronie, M., Gardan, D. A., Gardan, I. P., Andronie, I. E., \& Uta, C. (2019). Integrating the principles of green marketing by using big data: Good practices. Amfiteatru Economic, 21(50), 258-269. https://doi.org/10.24818/EA/2019/50/258

*Aquilani, B., Silvestri, C., Ioppolo, G., \& Ruggieri, A. (2018). The challenging transition to bio-economies: Towards a new framework integrating corporate sustainability and value co-creation. Journal of Cleaner Production, 172, 4001-4009. https://doi.org/10.1016/j.jclepro.2017.03.153

*Awasthi, M. K., Sarsaiya, S., Wainaina, S., Rajendran, K., Kumar, S., Quan, W., et al. (2019). A critical review of organic manure biorefinery models toward sustainable circular bioeconomy: Technological challenges, advancements, innovations, and future perspectives. Renewable and Sustainable Energy Reviews, 111, 115-131. https://doi.org/10.1016/j.rser.2019.05.017

*Barčić, A. P., Kuzman, M. K., Haviarova, E., \& Oblak, L. (2019). Circular economy and sharing collaborative economy principles: A case study conducted in wood-based sector. 12th International Scientific Conference WoodEMA-Digitalisation and circular economy: Forestry and forestry based inductry implications, 23-28.

Barnett, C., Cloke, P., Clarke, N., \& Malpass, A. (2011). Globalizing responsibility: The political rationalities of ethical consumption. Wiley-Blackwell.

*Bennich, T., Belyazid, S., Kopainsky, B., \& Diemer, A. (2018). The bio-based economy: Dynamics governing transition pathways in the Swedish forestry sector. Sustainability, 10, 976. https://doi.org/ $10.3390 /$ su 10040976 
Bertling, J., Borelbach, P., Hiebel, M., Kabasci, S., \& Kopitzky, R. (2018). Recycling of bioplasticsFraunhofer UMSICHT takes position. UMSICHT position papers. https://doi.org/10.24406/ UMSICHT-N-507110.

Bianchi, M. (Ed.). (1998). The active consumer: Novelty and surprise in consumer choice. Routledge.

*Biber-Freudenberger, L., Basukala, A., Bruckner, M., \& Börner, J. (2018). Sustainability performance of national bio-economies. Sustainability, 10, 2705. https://doi.org/10.3390/su10082705

Bioökonomierat. (2018). Bioeconomy Policy (Part III): Update report of national strategies around the world. A report from the German Bioeconomy Council. https://biooekonomierat.de/fileadmin/ Publikationen/berichte/GBS_2018_Bioeconomy-Strategies-around-the_World_Part-III.pdf.

Birch, K., Levidow, L., \& Papaioannou, T. (2010). Sustainable capital? The neoliberalization of nature and knowledge in the European "knowledge-based bio-economy." Sustainability, 2, 2898-2918. https://doi.org/10.3390/su2092898

Blok, V. (2020). What is innovation? Laying the ground for a philosophy of innovation. Techné: Research in Philosophy and Technology, 25, 1-15.

BMBF, \& BMEL. (2020). Nationale Bioökonomiestrategie. Berlin: Bundesministerium für Bildung und Forschung (BMBF) \& Bundesministerium für Ernährung und Landwirtschaft (BMEL).

BMEL. (2014). National policy strategy on bioeconomy: Renewable resources and biotechnological processes as a basis for food, industry and energy. Berlin.

Bogner, K. (2019). Knowledge networks in the German bioeconomy: Network structure of publicly funded R\&D networks. Hohenheim Discussion Papers in Business, Economics and Social Sciences No. 03-2019. Stuttgart: University of Hohenheim.

*Borge, L., \& Bröring, S. (2018). What affects technology transfer in emerging knowledge areas? A multi-stakeholder concept mapping study in the bioeconomy. The Journal of Technology Transfer, 33, 50. https://doi.org/10.1007/s10961-018-9702-4

*Borras, S. M., Franco, J. C., Isakson, S. R., Levidow, L., \& Vervest, P. (2016). The rise of flex crops and commodities: Implications for research. The Journal of Peasant Studies, 43, 93-115. https://doi. org/10.1080/03066150.2015.1036417

*Bracco, S., Calicioglu, O., Gomez San Juan, M., \& Flammini, A. (2018). Assessing the contribution of bioeconomy to the total economy: A review of national frameworks. Sustainability, 10, 1698. https://doi.org/10.3390/su10061698

*Brătucu, G., Constantin, C. P., Chițu, I. B., Grădinaru, E., \& Dovleac, L. (2019). Approaching the bioeconomy in terms of increasing the energy efficiency of households in Romania. Amfiteatru Economic, 21, 90-104.

*Brizga, J. (2019). Material flows, efficiency and decoupling: Latvia's case study. International Journal of Green Economics, 13, 55. https://doi.org/10.1504/IJGE.2019.101450

*Brown, W. F. (2000). NABC 12: An overview. In A. Eaglesham, W. F. Brown, \& R. W. F. Hardy (Eds.), NABC REPORT 12-The biobased economy of the twenty-first century: Agriculture expanding into health, energy, chemicals, and materials. National Agricultural Biotechnology Council.

*Bruckner, M., Häyhä, T., Giljum, S., Maus, V., Fischer, G., Tramberend, S., et al. (2019). Quantifying the global cropland footprint of the European Union's non-food bioeconomy. Environmental Research Letters, 14, 45011. https://doi.org/10.1088/1748-9326/ab07f5

Bugge, M., Hansen, T., \& Klitkou, A. (2016). What is the bioeconomy? A Review of the Literature. Sustainability, 8, 691. https://doi.org/10.3390/su8070691

Campbell, J. L., Quincy, C., Osserman, J., \& Pedersen, O. K. (2013). Coding in-depth semistructured interviews: Problems of unitization and intercoder reliability and agreement. Sociological Methods \& Research, 42(3), 294-320. https://doi.org/10.1177/0049124113500475

Cappellesso, G., \& Thomé, K. M. (2019). Technological innovation in food supply chains: Systematic literature review. British Food Journal. https://doi.org/10.1108/BFJ-03-2019-0160

Carus, M., Carrez, D., Kaeb, H., Ravenstijn, J., \& Venus, J. (2011). Level playing field for bio-based chemistry and materials: Policy paper on bio-based economy in the EU. Nova Institute, 4-18.

Chai, A., \& Baum, C. M. (Eds.). (2019). Demand, complexity, and long-run economic evolution. Springer.

*Cinelli, P., Coltelli, M. B., Signori, F., Morganti, P., \& Lazzeri, A. (2019). Cosmetic packaging to save the environment: Future perspectives. Cosmetics, 6, 26. https://doi.org/10.3390/COSMETICS6 020026

Coombs, R. (Ed.). (2001). Technology and the market: Demand, users and innovation. Elgar. 
D’Amato, D., Droste, N., Allen, B., Kettunen, M., Lähtinen, K., Korhonen, J., et al. (2017). Green, circular, bio economy: A comparative analysis of sustainability avenues. Journal of Cleaner Production, 168, 716-734. https://doi.org/10.1016/j.jclepro.2017.09.053

Daniel, H., \& Reisch, L. (2014). Konsum, Natur, Nachhaltigkeit: Warum Bioökonomie ohne Verhaltensänderungen nicht denkbar ist. Rundbrief Forum Umwelt and Entwicklung, 4, 5-6.

*de Jong, E., Higson, A., Walsh, P., \& Wellisch, M. (2012). Product developments in the bio-based chemicals arena. Biofuels, Bioproducts and Biorefining, 6, 606-624. https://doi.org/10.1002/bbb.1360

*de Schutter, G., Häyhä, B., Naqvi, O., et al. (2019). Bioeconomy transitions through the lens of coupled social-ecological systems: A framework for place-based responsibility in the global resource system. Sustainability, 11, 5705. https://doi.org/10.3390/su11205705

de Tavernier, J. (2012). Food citizenship: Is there a duty for responsible consumption? Journal of Agricultural and Environmental Ethics, 25, 895-907. https://doi.org/10.1007/s10806-011-9366-7

*Devaney, L., \& Henchion, M. (2018). Consensus, caveats and conditions: International learnings for bioeconomy development. Journal of Cleaner Production, 174, 1400-1411. https://doi.org/10. 1016/j.jclepro.2017.11.047

Devinney, T. M., Auger, P., \& Eckardt, G. M. (2010). The myth of the ethical consumer. Cambridge University Press.

de Vries, H., Donner, M., \& Axelos, M. (2021). A new conceptual "cylinder" framework for sustainable bioeconomy systems and their actors. Journal of Agricultural and Environmental Ethics, 34, 11. https://doi.org/10.1007/s10806-021-09850-7

Dickinson, R. A., \& Carsky, M. L. (2005). The consumer as economic voter. In R. Harrison, T. Newholm, \& D. Shaw (Eds.), The ethical consumer (pp. 25-36). Sage.

*Djokic, N., Grubor, A., Milicevic, N., \& Petrov, V. (2018). New market segmentation knowledge in the function of bioeconomy development in Serbia. Amfiteatru Economic, 20, 700-716. https:// doi.org/10.24818/EA/2018/49/700

*Dobrowolski, J. W., Bedla, D., Czech, T., Gambuś, F., Górecka, K., Kiszczak, W., et al. (2017). Integrated innovative biotechnology for optimization of environmental bioprocesses and a green economy. In H. J. Purohit, V. C. Kalia, A. N. Vaidya, \& A. A. Khardenavis (Eds.), Optimization and applicability of bioprocesses (Vol. 4, pp. 27-71). Springer.

*Dolgopolova, I., Teuber, R., Bruschi, V., Weber, G.-W., Danilenko, N., \& Galitskiy, E. (2017). Modelling consumer preferences for novel foods: Random utility and reference point effects approaches. In A. A. Pinto \& D. Zilberman (Eds.), Modeling, dynamics, optimization and bioeconomics II: DGS III, Porto, Portugal, February 2014, and Bioeconomy VII, Berkeley, USA, March 2014-Selected Contributions (pp. 165-182). Springer.

Dosi, G. (1982). Technological paradigms and technological trajectories. Research Policy, 11, 147162. https://doi.org/10.1016/0048-7333(82)90016-6

*Duchesne, L. C., \& Wetzel, S. (2003). The bioeconomy and the forestry sector: Changing markets and new opportunities. The Forestry Chronicle, 79, 860-864. https://doi.org/10.5558/tfc79 860-5

*Egenolf, V., \& Bringezu, S. (2019). Conceptualization of an indicator system for assessing the sustainability of the bioeconomy. Sustainability, 11(2), 443. https://doi.org/10.3390/su11020443

*Escobar, N., Haddad, S., Börner, J., \& Britz, W. (2018). Land use mediated GHG emissions and spillovers from increased consumption of bioplastics. Environmental Research Letters, 13, 125005. https://doi.org/10.1088/1748-9326/aaeafb

Etgar, M. (2008). A descriptive model of the consumer co-production process. Journal of the Academy of Marketing Science, 36, 97-108. https://doi.org/10.1007/s11747-007-0061-1

European Commission (EC). (2018a). A sustainable bioeconomy for Europe: Strengthening the connection between economy, society and the environment: Updated bioeconomy strategy. Publications Office of the European Union.

European Commission (EC). (2018b). Environmental impact assessment of innovative bio-based products. Brussels. https://publications.europa.eu/en/publication-detail/-/publication/15bb40e33979-11e9-8d04-01aa75ed71a1. Accessed 14 December 2020.

*Falcone, P. M., González García, S., Imbert, E., Lijó, L., Moreira, M. T., Tani, A., et al. (2019). Transitioning towards the bio-economy: Assessing the social dimension through a stakeholder lens. Corporate Social Responsibility and Environmental Management. https://doi.org/10.1002/ csr. 1791 
*Ferrazzi, G., Ventura, V., Ratti, S., \& Balzaretti, C. (2017). Consumers' preferences for a local food product: The case of a new Carnaroli rice product in Lombardy. Italian Journal of Food Safety, 6 , 6186. https://doi.org/10.4081/ijfs.2017.6186

*García, M., Alonso, Á., Tello, M. L., de La Poza, M., Villalobos, N., Lansac, R., et al. (2018). Editorial: Identifying agri-food research priorities for Spain-2017 results. Spanish Journal of Agricultural Research, 16, e0001. https://doi.org/10.5424/sjar/2018163-13587

*Gawel, E., Pannicke, N., \& Hagemann, N. (2019). A path transition towards a bioeconomy-The crucial role of sustainability. Sustainability, 11, 3005. https://doi.org/10.3390/su11113005

Geels, F. W. (2002). Technological transitions as evolutionary reconfiguration processes: A multi-level perspective and a1 case-study. Research Policy, 31, 1257-1274. https://doi.org/10.1016/S00487333(02)00062-8

*Gheorghe, I. R., Purcarea, V. L., \& Gheorghe, C. M. (2018). Consumer eWOM communication: The missing link between relational capital and sustainable bioeconomy in health care services. Amfiteatru Economic, 20, 684. https://doi.org/10.24818/EA/2018/49/684

*Gheorghe, I. R., Purcarea, V. L., \& Gheorghe, C. M. (2019). Pro-environmental behavior and bioeconomy: Reflections on single-bottled water consumption. Amfiteatru Economic, 21, 105. https:// doi.org/10.24818/EA/2019/50/105

Gianni, R., Pearson, J., \& Reber, B. (Eds.). (2019). Responsible research and innovation: From concepts to practices. Routledge.

Gjerris, M., Gamborg, C., \& Saxe, H. (2016). What to buy? On the complexity of being a critical consumer. Journal of Agricultural and Environmental Ethics, 29, 81-102. https://doi.org/10.1007/ s10806-015-9591-6

Godin, B., \& Lane, J. P. (2013). Pushes and Pulls. Science, Technology, and Human Values, 38, $621-654$. https://doi.org/10.1177/0162243912473163

Grabher, G., \& Ibert, O. (2018). Schumpeterian customers? How active users co-create innovations. In G. L. Clark, M. P. Feldman, M. S. Gertler, \& D. Wójcik (Eds.), The new Oxford handbook of economic geography. Oxford University Press.

Grabher, G., Ibert, O., \& Flohr, S. (2008). The neglected king: The customer in the new knowledge ecology of innovation. Economic Geography, 84, 253-280. https://doi.org/10.1111/j.1944-8287.2008. tb00365.x

Greening, L. A., Greene, D. L., \& Difiglio, C. (2000). Energy efficiency and consumption-the rebound effect-a survey. Energy Policy, 28, 389-401. https://doi.org/10.1016/S0301-4215(00)00021-5

Grefe, C. (2018). Dasselbe in Grün? Konfliktfelder, Konfliktlinien und Alternativen der Bioökonomie. Forum Wirtschaftsethik, 26 (Sonderausgabe Bioökonomie), 20-30.

*Grubor, A., Milicevic, N., \& Djokic, N. (2018). Serbian organic food consumer research and bioeconomy development. Sustainability, 10, 4820. https://doi.org/10.3390/su10124820

*Grundel, I., \& Dahlström, M. (2016). A quadruple and quintuple helix approach to regional innovation systems in the transformation to a forestry-based bioeconomy. Journal of the Knowledge Economy, 7, 963-983. https://doi.org/10.1007/s13132-016-0411-7

Grunwald, A. (2010). Wider die Privatisierung der Nachhaltigkeit-Warum ökologisch korrekter Konsum die Umwelt nicht retten kann. GAIA-Ecological Perspectives for Science and Society, 19, $178-182$.

Grunwald, A. (2012). Ende einer Illusion: Warum ökologisch korrekter Konsum uns nicht retten wird. Oekom.

*Hagemann, N., Gawel, E., Purkus, A., Pannicke, N., \& Hauck, J. (2016). Possible futures towards a wood-based bioeconomy: A scenario analysis for Germany. Sustainability, 8, 98. https://doi.org/10. 3390/su8010098

Hák, T., Janoušková, S., \& Moldan, B. (2016). Sustainable Development Goals: A need for relevant indicators. Ecological Indicators, 60, 565-573. https://doi.org/10.1016/j.ecolind.2015.08.003

Hausknost, D., Schriefl, E., Lauk, C., \& Kalt, G. (2017). A transition to which bioeconomy? An exploration of diverging techno-political choices. Sustainability, 9(4), 669. https://doi.org/10.3390/su904 0669

Heidbrink, L. (2013). Nichtwissen und Verantwortung: Zum Umgang mit nichtintendierten Handlungsfolgen. In C. Peter \& D. Funcke (Eds.), Wissen an der Grenze (pp. 111-139). Campus.

Heidbrink, L., \& Müller, S. (Eds.). (2020). Consumer Social Responsibility: Zur gesellschaftlichen Verantwortung von Konsumenten. Metropolis.

Heidbrink, L., \& Schmidt, I. (2011). Mehr Verantwortung für den Konsumenten. Ökologisches Wirtschaften-Fachzeitschrift, 26, 35. https://doi.org/10.14512/oew.v26i3.1144 
Herring, H., \& Roy, R. (2007). Technological innovation, energy efficient design and the rebound effect. Technovation, 27, 194-203. https://doi.org/10.1016/j.technovation.2006.11.004

*Hertel, T., Steinbuks, J., \& Baldos, U. (2013). Competition for land in the global bioeconomy. Agricultural Economics, 44, 129-138. https://doi.org/10.1111/agec.12057

Hoffmann, E. (2007). Consumer integration in sustainable product development. Business Strategy and the Environment, 16, 322-338. https://doi.org/10.1002/bse.577

Hübner, R., \& Schmon, B. (Eds.). (2019). Das transformative Potenzial von Konsum zwischen Nachhaltigkeit und Digitalisierung. Springer.

*Imbert, E. (2017). Food waste valorization options: Opportunities from the bioeconomy. Open Agriculture, 2, 438. https://doi.org/10.1515/opag-2017-0020

*Imbert, E., Ladu, L., Morone, P., \& Quitzow, R. (2017). Comparing policy strategies for a transition to a bioeconomy in Europe: The case of Italy and Germany. Energy Research and Social Science, 33, 70-81. https://doi.org/10.1016/j.erss.2017.08.006

*Imbert, E., Ladu, L., Tani, A., \& Morone, P. (2019). The transition towards a bio-based economy: A comparative study based on social network analysis. Journal of Environmental Management, 230, 255-265. https://doi.org/10.1016/j.jenvman.2018.09.068

*Issa, I., Delbrück, S., \& Hamm, U. (2019). Bioeconomy from experts' perspectives-Results of a global expert survey. PLoS ONE, 14, e0215917. https://doi.org/10.1371/journal.pone.0215917

Jacobsen, E., \& Dulsrud, A. (2007). Will Consumers save the world? The framing of political consumerism. Journal of Agricultural and Environmental Ethics, 20, 469-482. https://doi.org/10.1007/ s10806-007-9043-z

Jaeger-Erben, M., Rückert-John, J., \& Schäfer, M. (2015). Sustainable consumption through social innovation: A typology of innovations for sustainable consumption practices. Journal of Cleaner Production, 108, 784-798. https://doi.org/10.1016/j.jclepro.2015.07.042

*Jander, W., \& Grundmann, P. (2019). Monitoring the transition towards a bioeconomy: A general framework and a specific indicator. Journal of Cleaner Production, 236, 117564. https://doi.org/10. 1016/j.jclepro.2019.07.039

*Jarre, M., Petit-Boix, A., Priefer, C., Meyer, R., \& Leipold, S. (2020). Transforming the bio-based sector towards a circular economy-What can we learn from wood cascading? Forest Policy and Economics, 110, 101872. https://doi.org/10.1016/j.forpol.2019.01.017

Kallhoff, A. (2016). The normative limits of consumer citizenship. Journal of Agricultural and Environmental Ethics, 29, 23-34. https://doi.org/10.1007/s10806-015-9586-3

Kjærnes, U. (2012). Ethics and action: A relational perspective on consumer choice in the european politics of food. Journal of Agricultural and Environmental Ethics, 25, 145-162. https://doi.org/10. 1007/s10806-011-9315-5

Köhler, J., Geels, F. W., Kern, F., Markard, J., Onsongo, E., Wieczorek, A., et al. (2019). An agenda for sustainability transitions research: State of the art and future directions. Environmental Innovation and Societal Transitions, 31, 1-32. https://doi.org/10.1016/j.eist.2019.01.004

*Korhonen, J., Koskivaara, A., \& Toppinen, A. (2020). Riding a Trojan horse? Future pathways of the fiber-based packaging industry in the bioeconomy. Forest Policy and Economics, 110, 101799. https://doi.org/10.1016/j.forpol.2018.08.010

Korthals, M. (2001). Taking consumers seriously: Two concepts of consumer sovereignty. Journal of Agricultural and Environmental Ethics, 14, 201-215. https://doi.org/10.1023/A:1011356930245

Krippendorff, K. (2004). Content analysis: An introduction to its methodology (2nd ed.). Sage.

*Kristinsson, H. G., \& Jörundsdóttir, H. Ó. (2019). Food in the bioeconomy. Trends in Food Science and Technology, 84, 4-6. https://doi.org/10.1016/j.tifs.2018.10.011

*Kröber, B., \& Potthast, T. (2015). Bioeconomy and the future of food-ethical questions. In D. E. Dumitras, I. M. Jitea, \& S. Aerts (Eds.), Know your food: Food ethics and innovation (pp. 366371). Wageningen Academic Publishers.

*Kurppa, S. (2016). Regulatory policies and trends. In E. Iakovou, D. Bochtis, D. S. Vlachos, \& D. Aidonis (Eds.), Supply chain management for sustainable food networks (pp. 293-306). Wiley.

*Ladu, L., \& Blind, K. (2017). Overview of policies, standards and certifications supporting the European bio-based economy. Current Opinion in Green and Sustainable Chemistry, 8, 30-35. https:// doi.org/10.1016/j.cogsc.2017.09.002

Lamla, J., \& Neckel, S. (2006). Politisierter Konsum-konsumierte Politik. VS Verlag für Sozialwissenschaften. 
Landis, J. R., \& Koch, G. G. (1977). An application of hierarchical kappa-type statistics in the assessment of majority agreement among multiple observers. Biometrics, 33, 363. https://doi.org/10.2307/ 2529786

Lee, A. L. Y., Prendergast, G. P., Yim, F. H. K., \& Choi, L. (2019). A social dilemma perspective on recycling. Journal of Applied Social Psychology, 49, 585-595. https://doi.org/10.1111/jasp.12618

*Levidow, L. (2015). European transitions towards a corporate-environmental food regime: Agroecological incorporation or contestation? Journal of Rural Studies, 40, 76-89. https://doi.org/10.1016/j. jrurstud.2015.06.001

Levidow, L., Birch, K., \& Papaioannou, T. (2013). Divergent paradigms of European agro-food innovation. Science, Technology, and Human Values, 38, 94-125. https://doi.org/10.1177/0162243912 438143

Lewandowski, I. (2015). Securing a sustainable biomass supply in a growing bioeconomy. Global Food Security, 6, 34-42. https://doi.org/10.1016/j.gfs.2015.10.001

Loorbach, D., Wittmayer, J., Avelino, F., von Wirth, T., \& Frantzeskaki, N. (2020). Transformative innovation and translocal diffusion. Environmental Innovation and Societal Transitions. https://doi.org/ 10.1016/j.eist.2020.01.009

López Davis, S., Marín Rives, L., \& Ruiz de Maya, S. (2017). Introducing personal social responsibility as a key element to upgrade CSR. Spanish Journal of Marketing-ESIC, 21, 146-163. https://doi. org/10.1016/j.sjme.2017.04.001

Lundvall, B. - $\AA$. (2016). The learning economy and the economics of hope (Anthem studies in innovation and development). Anthem Press.

*Marsden, T., \& Farioli, F. (2015). Natural powers: From the bio-economy to the eco-economy and sustainable place-making. Sustainability Science, 10, 331-344. https://doi.org/10.1007/ s11625-014-0287-z

Martínez-Cañas, R., Ruiz-Palomino, P., Linuesa-Langreo, J., \& Blázquez-Resino, J. J. (2016). Consumer participation in co-creation: An enlightening model of causes and effects based on ethical values and transcendent motives. Frontiers in Psychology, 7, 793. https://doi.org/10.3389/fpsyg.2016. 00793

Mayring, P. (2014). Qualitative content analysis theoretical foundation, basic procedures and software solution. SSOAR.

Mayring, P. (2015). Qualitative content analysis: Theoretical background and procedures. In A. BiknerAhsbahs, C. Knipping, \& N. Presmeg (Eds.), Approaches to qualitative research in mathematics education: Examples of methodology and methods (pp. 365-380). Springer.

McCormick, K., \& Kautto, N. (2013). The bioeconomy in Europe: An overview. Sustainability, 5, 25892608. https://doi.org/10.3390/su5062589

McCormick, K., Neij, L., Mont, O., Ryan, C., Rodhe, H., \& Orsato, R. (2016). Advancing sustainable solutions: An interdisciplinary and collaborative research agenda. Journal of Cleaner Production, 123, 1-4. https://doi.org/10.1016/j.jclepro.2016.01.038

Meyer, R. (2017). Bioeconomy strategies: Contexts, visions, guiding implementation principles and resulting debates. Sustainability, 9, 1031. https://doi.org/10.3390/su9061031

Micheletti, M., Stolle, D., \& Berlin, D. (2012). Habits of sustainable citizenship: The example of political consumerism. In A. Warde \& D. Southerton (Eds.), The habits of consumption (pp. 141-163). Helsinki Collegium for Advanced Studies.

Minelgaitè, A., \& Liobikienè, G. (2019). Waste problem in European Union and its influence on waste management behaviours. The Science of the Total Environment, 667, 86-93. https://doi.org/10. 1016/j.scitotenv.2019.02.313

Moher, D., Liberati, A., Tetzlaff, J., \& Altman, D. G. (2009). Preferred reporting items for systematic reviews and meta-analyses: The PRISMA statement. BMJ, 339, b2535. https://doi.org/10.1136/ bmj.b2535

Möller, M., López, V., Prieß, R., Schleicher, T., Hünecke, K., Hennenberg, K., et al. (2020). Nachhaltige Ressourcennutzung-Anforderungen an eine nachhaltige Bioökonomie aus der Agenda 2030/SDGUmsetzung. Umweltbundesamt.

Moraes, C., Shaw, D., \& Carrigan, M. (2011). Purchase power: An examination of consumption as voting. Journal of Marketing Management, 27, 1059-1079. https://doi.org/10.1080/0267257X.2011. 565726

*Morone, P., Koutinas, A., Gathergood, N., Arshadi, M., \& Matharu, A. (2019). Food waste: Challenges and opportunities for enhancing the emerging bio-economy. Journal of Cleaner Production, 221, 10-16. https://doi.org/10.1016/j.jclepro.2019.02.258 
Mowery, D., \& Rosenberg, N. (1979). The influence of market demand upon innovation: A critical review of some recent empirical studies. Research Policy, 8, 102-153. https://doi.org/10.1016/ 0048-7333(79)90019-2

Müller, M. (2017). An agent-based model of heterogeneous demand. Springer.

Müller, S. (2020). Die soziale Verantwortung des Consumer Citizen. In L. Heidbrink \& S. Müller (Eds.), Consumer Social Responsibility: Zur gesellschaftlichen Verantwortung von Konsumenten (pp. 91-115). Metropolis.

Nelson, R. R., \& Consoli, D. (2010). An evolutionary theory of household consumption behavior. Journal of Evolutionary Economics, 20, 665-687. https://doi.org/10.1007/s00191-010-0171-7

O'Connor, C., \& Joffe, H. (2020). Intercoder reliability in qualitative research: Debates and practical guidelines. International Journal of Qualitative Methods, 19. https://doi.org/10.1177/1609406919 899220

Ober, S., \& Huwe, V. (2020). Teilhabe in der bioökonomischen Transformation: Technikfixierung bremst Bürgerbeteiligung. In oekom e.V. - Verein für ökologische Kommunikation (Ed.), BioökonomieWeltformel oder Brandbeschleuniger? Oekom.

*O'Brien, M., Wechsler, D., Bringezu, S., \& Schaldach, R. (2017). Toward a systemic monitoring of the European bioeconomy: Gaps, needs and the integration of sustainability indicators and targets for global land use. Land Use Policy, 66, 162-171. https://doi.org/10.1016/j.landusepol.2017.04.047

OECD. (2018). Meeting policy challenges for a sustainable bioeconomy. OECD Publishing.

Oekom e. V. (Ed.). (2020). Bioökonomie-Weltformel oder Brandbeschleuniger? Oekom.

Okoli, C. (2015). A guide to conducting a standalone systematic literature review. Communications of the Association for Information Systems. https://doi.org/10.17705/1CAIS.03743

de Olde, E. M., \& Valentinov, V. (2019). The moral complexity of agriculture: A challenge for corporate social responsibility. Journal of Agricultural and Environmental Ethics, 32, 413-430. https://doi. org/10.1007/s10806-019-09782-3

Otto, S., Beer, K., Henn, L., \& Overbeck, A. (2020). Das Individuum in der nachhaltigen Wirtschaft: Konsum in digitalen, algorithmenbasierten Entscheidungsarchitekturen. In A. Matheis \& C. Schwender (Eds.), Als gäbe es ein Morgen: Nachhaltigkeit wollen, sollen, können (pp. 409-426). Metropolis.

Otto, S., Hildebrandt, J., Will, M., Henn, L., \& Beer, K. (2021). Tying up loose ends: Integrating consumers' psychology into a broad interdisciplinary perspective on a circular sustainable bioeconomy. Journal of Agricultural and Environmental Ethics, 34, 8. https://doi.org/10.1007/ s10806-021-09851-6

Palmatier, R. W., Houston, M. B., \& Hulland, J. (2018). Review articles: Purpose, process, and structure. Journal of the Academy of Marketing Science, 46, 1-5. https://doi.org/10.1007/s11747-017-0563-4

*Parra-López, C., Holley, M., Lindegaard, K., Sayadi, S., Esteban-López, G., Durán-Zuazo, V. H., et al. (2017). Strengthening the development of the short-rotation plantations bioenergy sector: Policy insights from six European countries. Renewable Energy, 114, 781-793. https://doi.org/10.1016/j. renene.2017.07.098

*Pätäri, S., Arminen, H., Albareda, L., Puumalainen, K., \& Toppinen, A. (2017). Student values and perceptions of corporate social responsibility in the forest industry on the road to a bioeconomy. Forest Policy and Economics, 85, 201-215. https://doi.org/10.1016/j.forpol.2017.10.009

Persky, J. (1993). Retrospectives: Consumer sovereignty. Journal of Economic Perspectives, 7, $183-191$. https://doi.org/10.1257/jep.7.1.183

*Petig, E., Choi, H. S., Angenendt, E., Kremer, P., Grethe, H., \& Bahrs, E. (2019). Downscaling of agricultural market impacts under bioeconomy development to the regional and the farm level-An example of Baden-Wuerttemberg. GCB Bioenergy, 11, 1102-1124. https://doi.org/10.1111/gcbb. 12639

Pfau, S., Hagens, J., Dankbaar, B., \& Smits, A. (2014). Visions of sustainability in bioeconomy research. Sustainability, 6, 1222-1249. https://doi.org/10.3390/su6031222

*Plat, K., Meyer, A., Schneider, P., \& Perret, K. (2018). Potential for sustainable urban food production in a medium scale city in Germany. In W. Leal Filho, D. M. Pociovălișteanu, P. R. Borges de Brito, \& I. Borges de Lima (Eds.), Towards a sustainable bioeconomy: Principles, challenges and perspectives (pp. 233-260). Springer.

*Purkus, A., Gawel, E., \& Thrän, D. (2017). Addressing uncertainty in decarbonisation policy mixesLessons learned from German and European bioenergy policy. Energy Research and Social Science, 33, 82-94. https://doi.org/10.1016/j.erss.2017.09.020 
*Pyka, A. (2017). Dedicated innovation systems to support the transformation towards sustainability: Creating income opportunities and employment in the knowledge-based digital bioeconomy. Journal of Open Innovation: Technology, Market, and Complexity, 3, 385. https://doi.org/10.1186/ s40852-017-0079-7

Pyka, A. (2019). Evolutorische Innovationsökonomik. In B. Blättel-Mink, I. Schulz-Schaeffer, \& A. Windeler (Eds.), Handbuch Innovationsforschung (pp. 1-19). Springer.

Pyka, A. (2020). The bioeconomy from the point of view of innovation economics. In J. Pietzsch (Ed.), Bioeconomy for beginners (pp. 129-138). Springer.

*Pyka, A., \& Prettner, K. (2018). Economic growth, development, and innovation: The transformation towards a knowledge-based bioeconomy. In I. Lewandowski (Ed.), Bioeconomy (pp. 331-342). Springer.

*Ranacher, L., Höfferer, K., Lettner, M., Hesser, F., Stern, T., Rauter, R., et al. (2018). What would potential future opinion leaders like to know? An explorative study on the perceptions of four woodbased innovations. Die Bodenkultur: Journal of Land Management, Food and Environment, 69, 47-59. https://doi.org/10.2478/boku-2018-0005

Randelli, F., \& Rocchi, B. (2017). Analysing the role of consumers within technological innovation systems: The case of alternative food networks. Environmental Innovation and Societal Transitions, 25, 94-106. https://doi.org/10.1016/j.eist.2017.01.001

Roberts, D., Hughes, M., \& Kertbo, K. (2014). Exploring consumers' motivations to engage in innovation through co-creation activities. European Journal of Marketing, 48, 147-169. https://doi.org/ 10.1108/EJM-12-2010-0637

Rogers, E. M. (2003). Diffusion of Innovations. Free Press.

Rommerskirchen, J. (Ed.). (2020). Die neue Macht der Konsumenten. Springer.

Røpke, I. (2013). Ecological macroeconomics: Implications for the roles of consumer-citizens. In M. J. Cohen, H. S. Brown, \& P. Vergragt (Eds.), Innovations in sustainable consumption: New economics, socio-technical transitions and social practices (pp. 48-64). Edward Elgar.

Rösch, C., \& Scheer, D. (2020). Wege zu einer ressourceneffizienten Bioökonomie: Weniger ist mehr. In oekom e.V. - Verein für ökologische Kommunikation (Ed.), Bioökonomie-Weltformel oder Brandbeschleuniger? (pp. 84-89). Oekom.

*Rudolph, K. (2018). Barriers to acceptance of bio-based substitutes: How schema incongruity can hinder the purchase of bio-based products. In W. Leal Filho, D. M. Pociovălișteanu, P. R. Borges de Brito, \& I. Borges de Lima (Eds.), Towards a sustainable bioeconomy: Principles, challenges and perspectives (pp. 117-133). Springer.

*Santeramo, F. G., Carlucci, D., de Devitiis, B., Nardone, G., \& Viscecchia, R. (2017). On consumption patterns in oyster markets: The role of attitudes. Marine Policy, 79, 54-61. https://doi.org/10. 1016/j.marpol.2017.02.005

Sanz-Hernández, A., Esteban, E., \& Garrido, P. (2019). Transition to a bioeconomy: Perspectives from social sciences. Journal of Cleaner Production, 224, 107-119. https://doi.org/10.1016/j.jclepro. 2019.03.168

Schlaile, M. P., Klein, K., \& Böck, W. (2018a). From bounded morality to consumer social responsibility: A transdisciplinary approach to socially responsible consumption and its obstacles. Journal of Business Ethics, 149, 561-588. https://doi.org/10.1007/s10551-016-3096-8

Schlaile, M. P., Klein, K., \& Böck, W. (2020). Konsumentenverantwortung: Konzeptualisierungsversuche vor dem Hintergrund einer "bounded morality.” In L. Heidbrink \& S. Müller (Eds.), Consumer Social Responsibility: Zur gesellschaftlichen Verantwortung von Konsumenten (pp. 71-90). Metropolis.

Schlaile, M. P., Mueller, M., Schramm, M., \& Pyka, A. (2018b). Evolutionary economics, responsible innovation and demand: Making a case for the role of consumers. Philosophy of Management, 17, 7-39. https://doi.org/10.1007/s40926-017-0054-1

Schlaile, M. P., Urmetzer, S., Blok, V., Andersen, A., Timmermans, J., Mueller, M., et al. (2017). Innovation systems for transformations towards sustainability? Taking the normative dimension seriously. Sustainability, 9, 2253. https://doi.org/10.3390/su9122253

Schlaile, M. P., \& Urmetzer, S. (2021). Transitions to sustainable development. In W. Leal Filho, A. M. Azul, L. Brandli, A. Lange Salvia, \& T. Wall (Eds.), Encyclopedia of the UN Sustainable Development Goals: Decent Work and Economic Growth (pp. 1067-1081). Springer.

Schmidt, I. (2016). Consumer Social Responsibility: Gemeinsame Verantwortung für nachhaltiges Konsumieren und Produzieren. Springer. 
Schmidt, I. (2017). Konsumentenverantwortung. In L. Heidbrink, C. Langbehn, \& J. Loh (Eds.), Handbuch Verantwortung (pp. 735-764). Springer.

Schmidt, I. (2020). Consumer Social Responsibility-Theoretische und praktische Grundlagen. In L. Heidbrink \& S. Müller (Eds.), Consumer Social Responsibility: Zur gesellschaftlichen Verantwortung von Konsumenten (pp. 15-33). Metropolis.

Schmookler, J. (1962). Economic sources of inventive activity. The Journal of Economic History, 22, 1-20. https://doi.org/10.1017/S0022050700102311

Schrader, U. (2007). The moral responsibility of consumers as citizens. International Journal of Innovation and Sustainable Development, 2, 79. https://doi.org/10.1504/IJISD.2007.016059

Schumpeter, J. A. (1943). Capitalism. Socialism and Democracy. Routledge.

Schumpeter, J. A. (1983). The theory of economic development: An inquiry into profits, capital, credit, interest and the business cycle (16th edition, Social science classics series). Transaction Publishers.

Senge, P. M., \& Carstedt, G. (2003). Innovating our way to the next industrial revolution. In M. S. Scott Morton, R. Laubacher, \& T. W. Malone (Eds.), Inventing the organizations of the 21st century (pp. 389-412). MIT Press.

Shaw, D., Newholm, T., \& Dickinson, R. (2006). Consumption as voting: An exploration of consumer empowerment. European Journal of Marketing, 40, 1049-1067. https://doi.org/10.1108/03090 560610681005

Shove, E. (2010). Beyond the ABC: Climate change policy and theories of social change. Environment and Planning A: Economy and Space, 42, 1273-1285. https://doi.org/10.1068/a42282

*Smolker, R. (2008). The new bioeconomy and the future of agriculture. Development, 51, 519-526. https:// doi.org/10.1057/dev.2008.67

*Söderholm, K., Bergquist, A.-K., \& Söderholm, P. (2017). The transition to chlorine free pulp revisited: Nordic heterogeneity in environmental regulation and R\&D collaboration. Journal of Cleaner Production, 165, 1328-1339. https://doi.org/10.1016/j.jclepro.2017.07.190

*Soetaert, W., \& Vandamme, E. (2006). The impact of industrial biotechnology. Biotechnology Journal, 1, 756-769. https://doi.org/10.1002/biot.200600066

Sonck, M., Asveld, L., \& Osseweijer, P. (2020). Meta-responsibility in corporate research and innovation: A bioeconomic case study. Sustainability, 12, 38. https://doi.org/10.3390/su12010038

Srnka, K. J., \& Schweitzer, F. M. (2000). Macht Verantwortung und Information: Der Konsument als Souverän? Zfwu Zeitschrift Für Wirtschafts-Und Unternehmensethik, 1, 192-205. https://doi.org/10.5771/ 1439-880X-2000-2-192

Staffas, L., Gustavsson, M., \& McCormick, K. (2013). Strategies and policies for the bioeconomy and biobased economy: An analysis of official national approaches. Sustainability, 5, 2751-2769. https://doi. org/10.3390/su5062751

*Stern, T., Ploll, U., Spies, R., Schwarzbauer, P., Hesser, F., \& Ranacher, L. (2018). Understanding perceptions of the bioeconomy in Austria-An explorative case study. Sustainability, 10, 4142. https://doi. org/10.3390/su10114142

Swann, G. M. P. (2009). The economics of innovation: An introduction. Edward Elgar.

Székács, A. (2017). Environmental and ecological aspects in the overall assessment of bioeconomy. Journal of Agricultural and Environmental Ethics, 30, 153-170. https://doi.org/10.1007/s10806-017-9651-1

Teece, D. J. (1986). Profiting from technological innovation: Implications for integration, collaboration, licensing and public policy. Research Policy, 15, 285-305. https://doi.org/10.1016/0048-7333(86) 90027-2

Tempels, T., Blok, V., \& Verweij, M. (2017). Understanding political responsibility in corporate citizenship: Towards a shared responsibility for the common good. Journal of Global Ethics, 13, 90-108. https:// doi.org/10.1080/17449626.2017.1320577

Tempels, T., Blok, V., \& Verweij, M. (2020). Injustice in food-related public health problems: A matter of corporate responsibility. Business Ethics Quarterly. https://doi.org/10.1017/beq.2019.41

The White House. (2012). National Bioeconomy Blueprint. Washington D.C. https://obamawhitehouse.archi ves.gov/sites/default/files/microsites/ostp/national_bioeconomy_blueprint_april_2012.pdf. Accessed 19 Nov 2019.

*Toppinen, A., Autio, M., Sauru, M., \& Berghäll, S. (2018a). Sustainability-driven new business models in wood construction towards 2030. In W. Leal Filho, D. M. Pociovălișteanu, P. R. Borges de Brito, \& I. Borges de Lima (Eds.), Towards a sustainable bioeconomy: Principles, challenges and perspectives (pp. 499-516). Springer. 
*Toppinen, A., Pätäri, S., Tuppura, A., \& Jantunen, A. (2017). The European pulp and paper industry in transition to a bio-economy: A Delphi study. Futures, 88, 1-14. https://doi.org/10.1016/j.futures.2017. 02.002

*Toppinen, A., Röhr, A., Pätäri, S., Lähtinen, K., \& Toivonen, R. (2018b). The future of wooden multistory construction in the forest bioeconomy-A Delphi study from Finland and Sweden. Journal of Forest Economics, 31, 3-10. https://doi.org/10.1016/j.jfe.2017.05.001

Tranfield, D., Denyer, D., \& Smart, P. (2003). Towards a methodology for developing evidence-informed management knowledge by means of systematic review. British Journal of Management, 14, 207-222. https://doi.org/10.1111/1467-8551.00375

*Tsimitri, P., Michailidis, A., Loizou, E., Mantzouridou, F. T., Gkatzionis, K., \& Mugampoza, E. (2018). Bioeconomy and the production of novel food products from agro-industrial wastes and residues under the context of food neophobia. AgBioforum, 21(2), 97-106.

Urmetzer, S. (2020). The bioeconomy: A knowledge-based innovation paradigm to foster sustainability transformations. Doctoral Thesis. University of Hohenheim. http://opus.uni-hohenheim.de/volltexte/2020/ 1761/pdf/Dissertation_Sophie_Urmetzer_2020.pdf. Accessed 11 Nov 2020.

Urmetzer, S., \& Pyka, A. (2021). Innovation systems for sustainability. In W. Leal Filho, A. M. Azul, L. Brandli, S. Amanda Lange, \& T. Wall (Eds.), Encyclopedia of the UN Sustainable Development Goals: Decent work and economic growth (pp. 600-611). Springer.

Urmetzer, S., Schlaile, M. P., Bogner, K., Mueller, M., \& Pyka, A. (2018). Exploring the dedicated knowledge base of a transformation towards a sustainable bioeconomy. Sustainability, 10, 1694. https://doi. org/10.3390/su10061694

Urmetzer, S., Schlaile, M. P., Bogner, K., Mueller, M., \& Pyka, A. (2020). Wissen für den Wandel-Wissenstheoretische Grundlagen einer nachhaltigen Bioökonomiepolitik. In W. Konrad, D. Scheer, \& A. Weidtmann (Eds.), Bioökonomie nachhaltig gestalten: Perspektiven für ein zukunftsfähiges Wirtschaften (pp. 73-105). Springer.

*Vandermeulen, V., van der Steen, M., Stevens, C. V., \& van Huylenbroeck, G. (2012). Industry expectations regarding the transition toward a biobased economy. Biofuels, Bioproducts and Biorefining, 6, 453-464. https://doi.org/10.1002/bbb.1333

*Varela-Candamio, L., Calvo, N., \& Novo-Corti, I. (2018). The role of public subsidies for efficiency and environmental adaptation of farming: A multi-layered business model based on functional foods and rural women. Journal of Cleaner Production, 183, 555-565. https://doi.org/10.1016/j.jclepro.2018.02. 109

Vargo, S. L., Akaka, M. A., \& Wieland, H. (2020). Rethinking the process of diffusion in innovation: A service-ecosystems and institutional perspective. Journal of Business Research, 116, 526-534. https:// doi.org/10.1016/j.jbusres.2020.01.038

*Vatamanescu, E.-M., Alexandru, V.-A., Cristea, G., Radu, L., \& Chirica, O. (2018). A demand-side perspective of bioeconomy: The influence of online intellectual capital on consumption. Amfiteatru Economic, 20, 536-552. https://doi.org/10.24818/EA/2018/49/536

*Vita, G., Lundström, J. R., Hertwich, E. G., Quist, J., Ivanova, D., Stadler, K., et al. (2019). The environmental impact of green consumption and sufficiency lifestyles scenarios in Europe: Connecting local sustainability visions to global consequences. Ecological Economics, 164, 106322. https://doi.org/10. 1016/j.ecolecon.2019.05.002

Vivien, F.-D., Nieddu, M., Befort, N., Debref, R., \& Giampietro, M. (2019). The hijacking of the bioeconomy. Ecological Economics, 159, 189-197. https://doi.org/10.1016/J.ECOLECON.2019.01.027

Vogt, M. (2018). Bedingungen ethisch verantwortbarer Bioökonomie. Forum Wirtschaftsethik, 26 (Sonderausgabe Bioökonomie), 31-51.

Vogt, M. (2020). Bioökonomie aus ethischer Perspektive: Horizonterweiterung zulassen. In oekom e.V. Verein für ökologische Kommunikation (Ed.), Bioökonomie-Weltformel oder Brandbeschleuniger? (pp. 26-31). Oekom.

*Voisin, S., \& Fréon, P. (2014). Fisheries and aquaculture sustainability. In A. Monaco \& P. Prouzet (Eds.), Value and economy of marine resources (pp. 53-151). ISTE Ltd and John Wiley \& Sons.

*von Braun, J. (2018). Bioeconomy-The global trend and its implications for sustainability and food security. Global Food Security, 19, 81-83. https://doi.org/10.1016/j.gfs.2018.10.003

von Hippel, E. (2005). Democratizing innovation. MIT Press.

von Hippel, E. (2017). Free innovation. MIT Press.

von Hippel, E., Ogawa, S., \& de Jong, J. P. J. (2011). The age of the consumer-innovator. MIT Sloan Management Review, 53(1), 27-35. 
von Schomberg, R., \& Hankins, J. (Eds.). (2019). International handbook on responsible innovation. Edward Elgar.

WBGU. (2011). World in transition: A social contract for sustainability. German Advisory Council on Global Change WBGU.

*Winkler, B., Maier, A., \& Lewandowski, I. (2019). Urban gardening in Germany: Cultivating a sustainable lifestyle for the societal transition to a bioeconomy. Sustainability, 11, 801. https://doi.org/10.3390/ su11030801

Young, I. M. (2006). Responsibility and global justice: A social connection model. Social Philosophy and Policy, 23, 102-130. https://doi.org/10.1017/S0265052506060043

*Zilberman, D., Graff, G., Hochman, G., \& Kaplan, S. (2015). The political economy of biotechnology. German Journal of Agricultural Economics, 64(4), 212-223. https://doi.org/10.22004/ag.econ.270180

Zink, T., \& Geyer, R. (2017). Circular economy rebound. Journal of Industrial Ecology, 21, 593-602. https:// doi.org/10.1111/jiec. 12545

Zwier, J., Blok, V., Lemmens, P., \& Geerts, R.-J. (2015). The ideal of a zero-waste humanity: Philosophical reflections on the demand for a bio-based economy. Journal of Agricultural and Environmental Ethics, 28, 353-374. https://doi.org/10.1007/s10806-015-9538-y

Note: References marked with * indicate studies included in the (final sample of the) literature review.

Publisher's Note Springer Nature remains neutral with regard to jurisdictional claims in published maps and institutional affiliations.

\section{Authors and Affiliations}

\section{Ulrich Wilke $^{1}$ (D) Michael P. Schlaile ${ }^{2,3}$ (D) Sophie Urmetzer ${ }^{2,4}$ (D) Matthias Mueller ${ }^{2}$. Kristina Bogner ${ }^{5}$ - Andreas Pyka ${ }^{2} \mathbb{D}$}

Ulrich Wilke

ulrich.wilke@ reutlingen-university.de

Sophie Urmetzer

sophie.urmetzer@uni-hohenheim.de

Matthias Mueller

m_mueller@uni-hohenheim.de

Kristina Bogner

kristina.bogner@uni-hohenheim.de

Andreas Pyka

a.pyka@uni-hohenheim.de

1 Reutlingen University, Alteburgstraße 150, 72762 Reutlingen, Germany

2 Department of Innovation Economics (520I), University of Hohenheim, Wollgrasweg 23, 70599 Stuttgart, Germany

3 Institut für Ökonomie, Cusanus Hochschule für Gesellschaftsgestaltung, Postfach 1146, 54461 Bernkastel-Kues, Germany

4 Coordination Office Bioeconomy Research Baden-Württemberg, University of Hohenheim, Wollgrasweg 43, 70599 Stuttgart, Germany

5 Innovation Greenhouse, University of Hohenheim, Schloss Hohenheim 1, 70599 Stuttgart, Germany 